الامن النفسيّ وعلاقته بالتوافق الجامعيّ

لاى طلبة كلية التربية في الجامعة المستتصرية

أ.م.د عبد الحسين رزوقي مجيد

م.د حيدر لازم خضير

م.د ـاثير عداي سلمان القريشي

الملخص : ئدّ الأمن النفسي احد أهم محركات العالم الحديث حيث ازدادت البحوث التي تتاولته لأهميته وتأثيره في كثثر من الجوانب السياسية والاقتصادية و النفسية ولاسيما عند شريحة طلبة الجامعة الذين يعدون من أهم

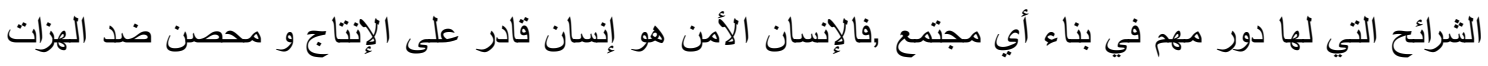

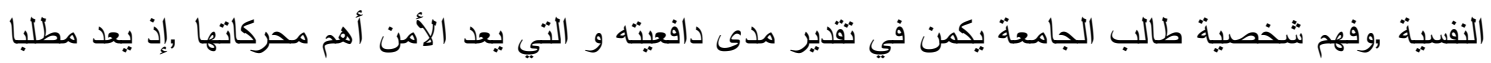
رئيسيا للتوافق ,فالإنسان الأمن هو الذي يكون قادر على بناء علاقات ناجحة مع الآخرين.

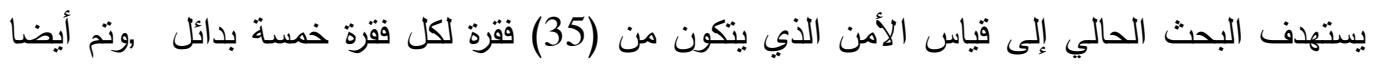
تبني مقياس التوافق الجامعي الذي أعدته الجنابي، (2008) والذي يتكون من الأن (44) فقرة لكل منها خمسة بدائل رحيث نم التحقق من الصدق والثبات وتم تطبيقه على عينة مكونة من (100)طالب وطالبة في كلية التربية ,

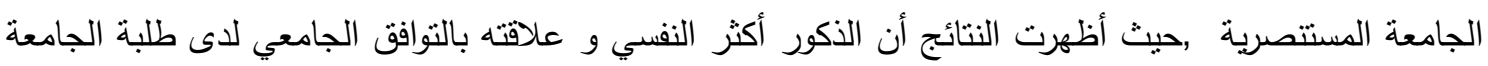
والذي أعده سلطان (2002,) بعد تكييفه ليتلاءم وطلبة الجامعة و تنين ان الذكور اكثر أمنا من الإناث و تنين عدم وجود فروق واضحة في التوافق الجامعي بين الجنسين.

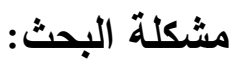

إنَّ السمات الاساسية لهذا العصر هو التغير السريع العلمي والتقني وكذلك التغيرات السياسية والاجتماعيـة والثقافيـة التي اثرت على نفسية طلبـة الجامعـة ويشكل خاص على حاجتهم للأكـن

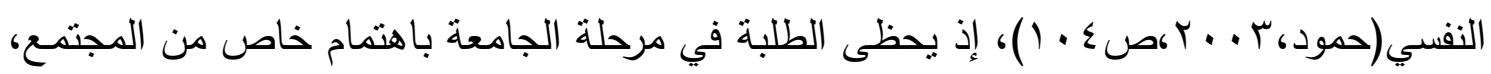

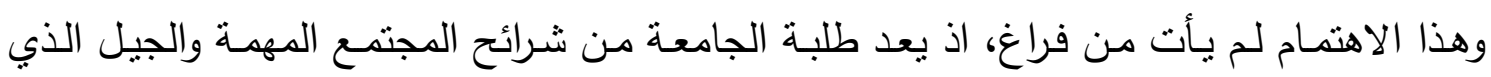
يتحمل اعباء المسؤولية، ويواجه الصعوبات والتحديات وهذا الاهتمام ينبغي ان لا يشمل الجانب

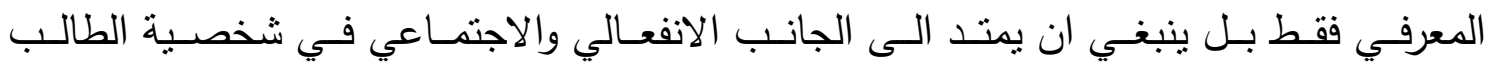

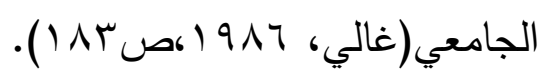

إنَّ الاسـاس الاهم الذي يقوم عليه فهم شخصية الطالب يكمن في تقدير مصـادر الدافعيـة التي تقف وراء سـوكه الظـاهر وان هذا الاسـاس يكمن في معرفـة حاجاته والقوى الحقيقيـة التي تقف وراء استمرار سـوكه ومـن ابـرز هذه الحاجـات الحاجـة الى الثـعور بـالأمن النفسي (عبد

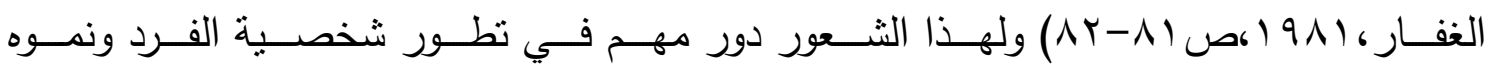
المعرفي(Fatil\&Reddy,1985,p.12). 


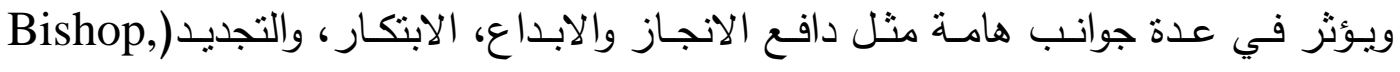

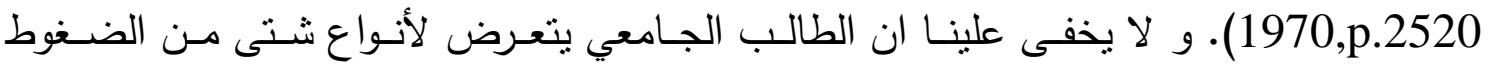

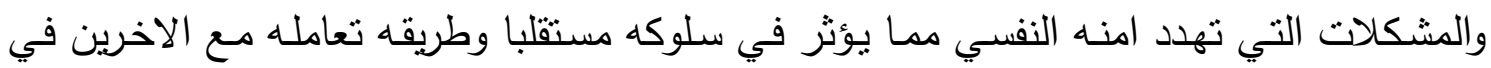

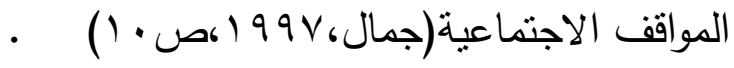

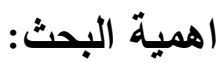

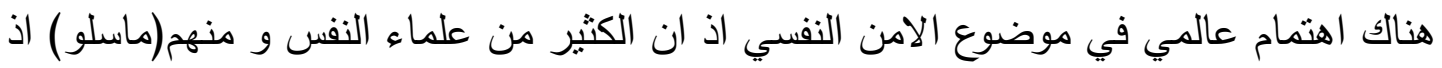

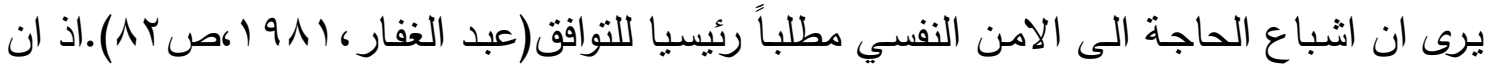

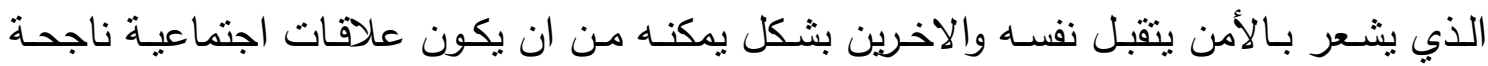

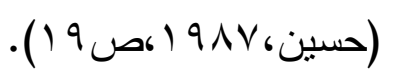

ويرى(ماسـلو) ان الحاجـة الـى الامـن تظهر اهميتهـا بوضـوح وخاصـة لدى الكبـار وجوهرهـا

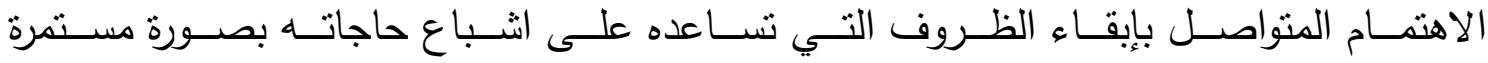

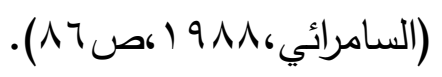

ويرى(فهرير ) ان الثشباب اكثر تعرضـنا للثـعور بعدم الامـن النفسي مـن كبـار السـن وقد

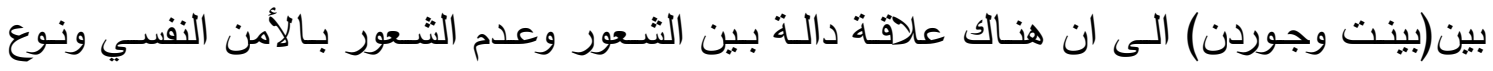
الاستجابات ذات النزعة العدوانية للاحباط(167-Bennet \&jordn,1985,p.166). ويرى (فرويد) ان سبل الفرد والياته الدفاعية اللاشعورية الي وصفها بانها محاولة نفسية غير

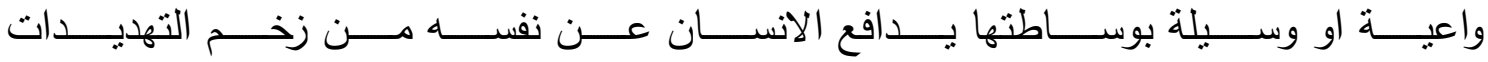
والاخطار (Lazarus,1969,p.85). كما ان البئية تحتوي على ما هو غير آمن فهي تهدد ولها القدرة على احداث الالم وزيادة التوتر

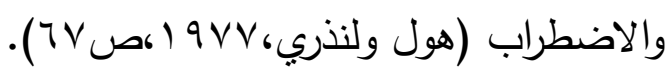
ان الخوف والقلق وغياب الاستقرار الكثير و من اضطرابات الثخصية وهي بعض بنتائج فقدان الامن النفسي، وفي ذلك يشير (ماسلو) الى ان انماطـا معينة من المصابين بالعصـاب مدفوعون بدرجة كبيرة للبحث عن اشباع حاجاتهم الى الامن- (395-390 CoLe\&Hell,1970,pp.39 ). فاذا شعر الانسان بأية صعوبة في انشباع حاجاته الاساسية في المستقبل احس بالقلق وشعر الأدر بعدم

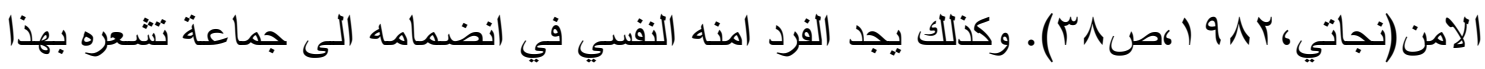

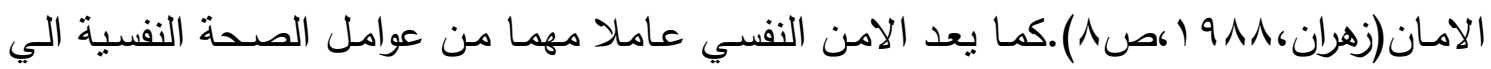

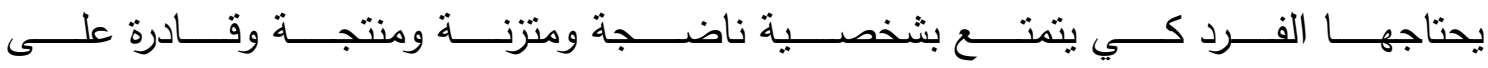

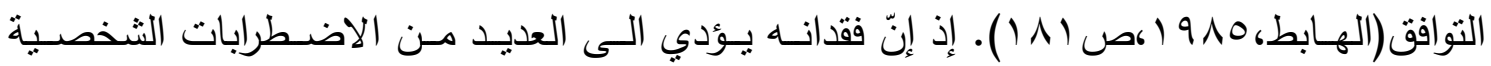

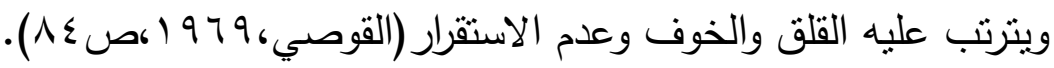


ويمثل الثباب في اي مجتمع طاقة كبيره واداة البناء الرئيسية، وان طلبة الجامعة في اي مجتمع هم الثريحة المهمة والجيل الذي ينحمل المسؤولية في مواجهة التحديات والصعوبات في معظم نواحي الحياة، اذ اصبحت الثـهادة الجامعيـة هي الاسـاس لكل وظيفة والمعيار لنواحي الحيـاة

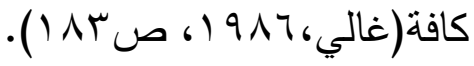
لذا فان عملية النوافق ذات بعد كبير فيما يخص الطالب لما لـه من اهمية في طريقة تفاعله

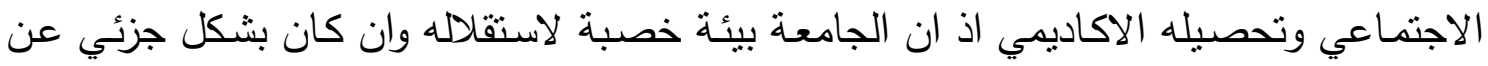

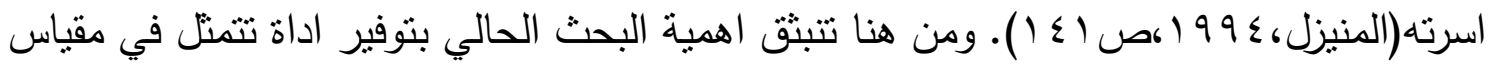

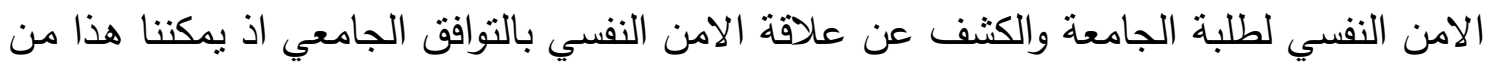

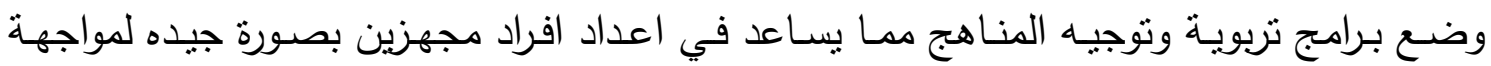
صعوبات الحياه ومتطلبات سوق العمل.

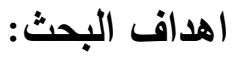

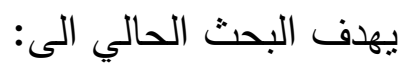

ا التعرف على مستوى الامن النفسي لاى طلبة الجامعة. r.معرفة الفرق بين(الذكور والاناث). بـالتعرف على مستوى التوافق الجامعي.

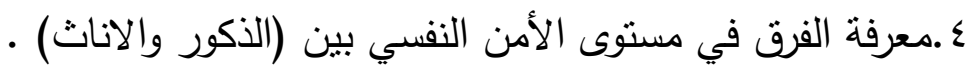

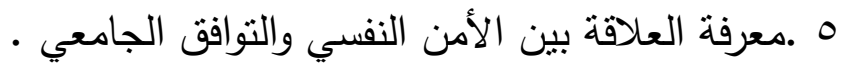

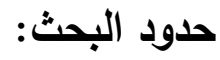
يقتصـر البحـث الحـالي على طلبـة الجامعـة المستتصـرية كليـة التربيـة المرحلـة الثالثـة للعـام

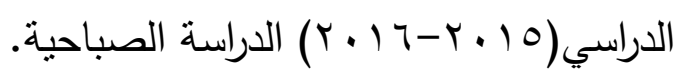
تحديد المصطلحات:

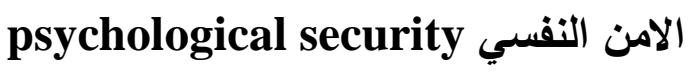
عرفه ادلر بانه"الوضعية التي يكون فيها الفرد امنا ومتحررا من التهايد والخطر بالثكل الذي يمكنه من الوجود بوضعية قوية من دون وجود التحديات(Fatil \& Reddy, 1985, p.12). ماسـو "ثـعور الفرد القبول والانتماء والالفة وندرة الثتعور بالتهديد والخطر والقلق، يتصور بان بان

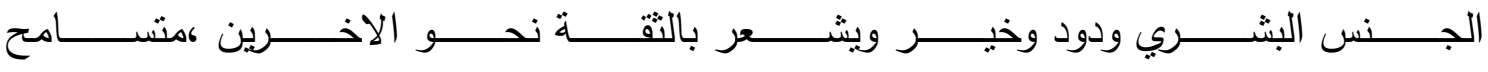
ومتعاطف"(Maslow,1972,p.36).

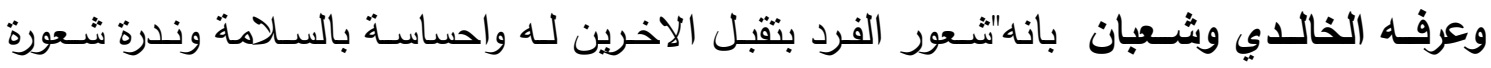

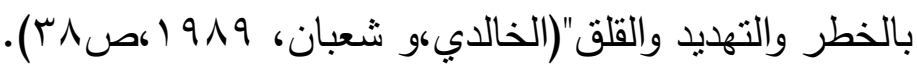


وعرفــه هوســفمان "ثــور بالاطمئنـان والسـعادة والســلامة مـن المـرض وتجنـب الالــم" .(Husffman,2000,p.407) ويعرفه الباحثون نظريا: بانه الثعور بالاطمئنان والاستقرار النفسي وتجنب الخوف والالم.

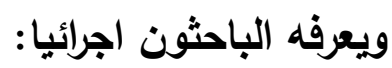

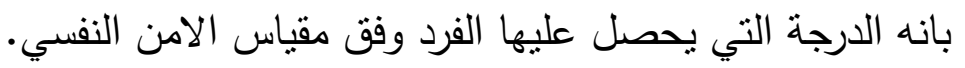
التوافق الجامعي:University Adjustment التوافق:Adjustment عرفـة كـود "انـه عمليـة اكتسـاب وتبني اسـاليب مـن السلوك تكون ملائمـة للبيئة او للتغيـرات فيها")(Good 1973,p.12). ابو النيل وزيور "قدره الفرد على التواؤم مـع نفسه ومـع السياق الاجتماعي الذي يعيش فيه من

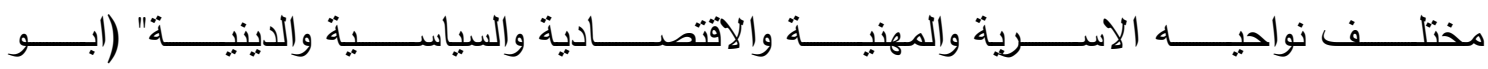

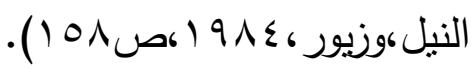

الـليمي "عمليـة نفاعل الانسـان باستمرار مـع بيئته الماديــة والاجتماعيـة وهذا التفاعل عمليـة

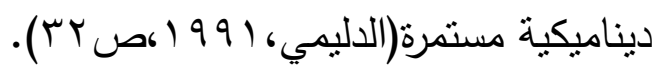

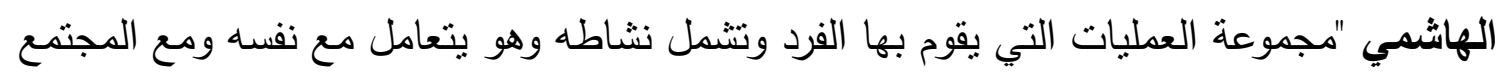

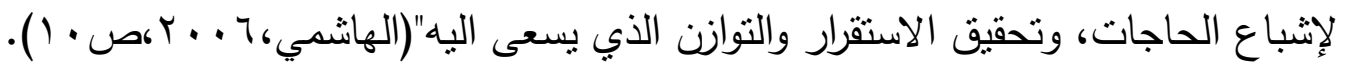
ويعرف نظريا

بانه الاتصال المستمر بين الفرد ومجاله الديوي للوصول الى حالة من التوازن والاستقرار .

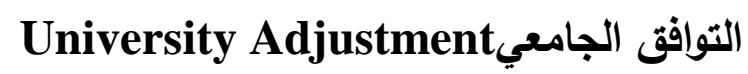
عرفه الزيادي "بانه القدرة على اقامة العلالاقات الاجتماعية المستمره والممتعه ميع الاخرين بحيث

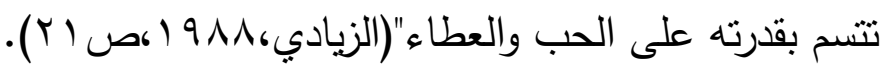

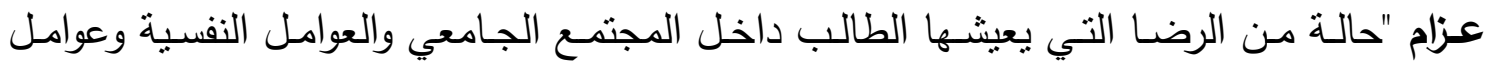

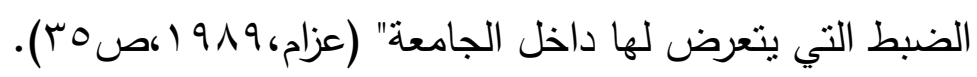

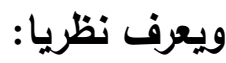
بانـه قدره الطالب على التوافق مـع قابليته وامكانياته الاجتماعيـة ورضـاه عن علاقاته ومكانته

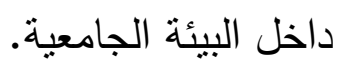
ويعرف الباحثون اجرائيا بانه الدرجة التي يحصل عليها الطالب على وفق مقياس التوافق الجامعي. 
الاطار النظري والدراسات السابقة: الاطار النظري/ الامن النفسيّ: إنّ الامن النفسي يعني التحرر من الخوف ايا كان مصدر فيشعر الفرد انه محبوب ومقبول

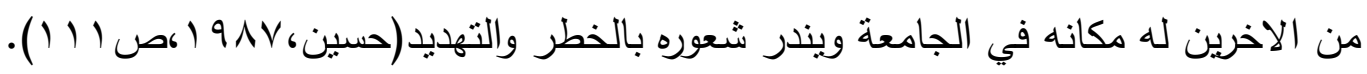

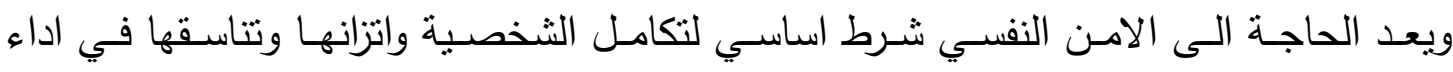

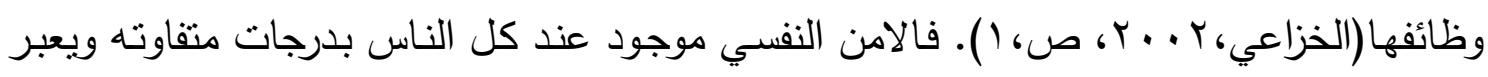

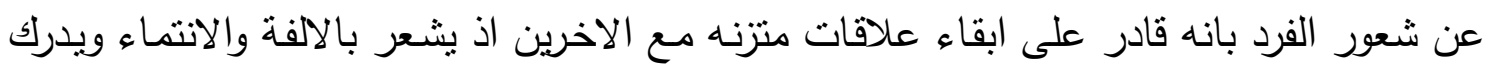

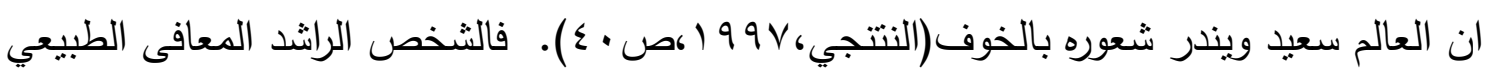

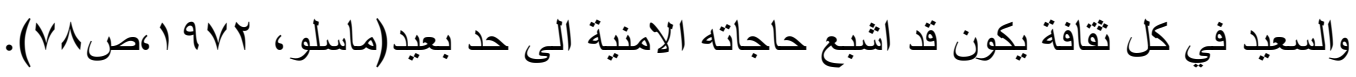
وهنا نورد بعض النظريات الي حاولت تقديم بعض التفسيرات: اتجاه التحليل النفسي: ووفقا فرويد تتكون الثخصية من ثلاثة مكونات هي الهو والانا والانـا الاعلى وتتتافس هذه

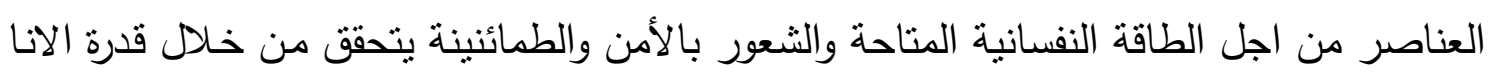

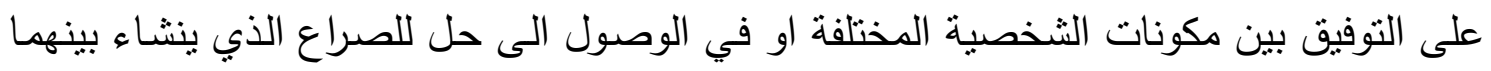

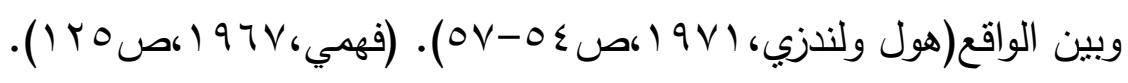

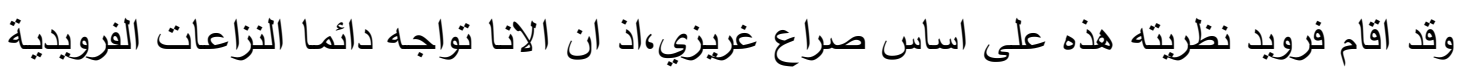

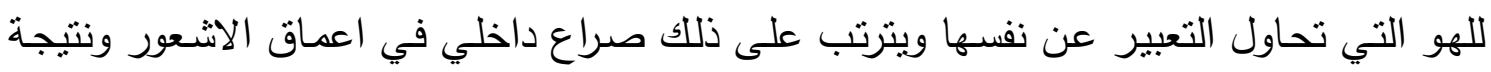

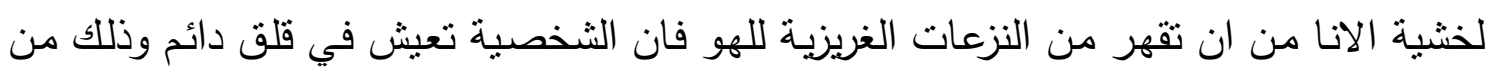

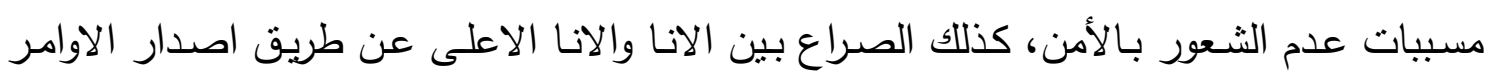

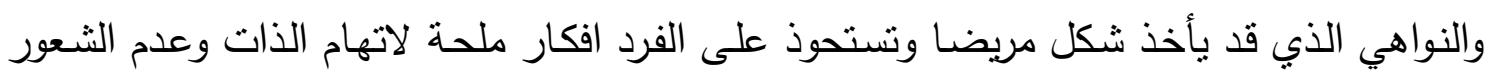

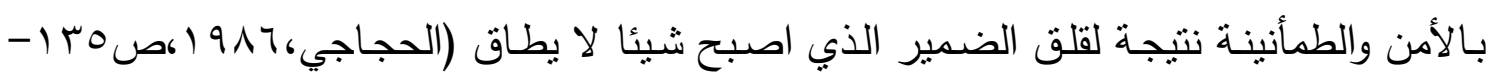

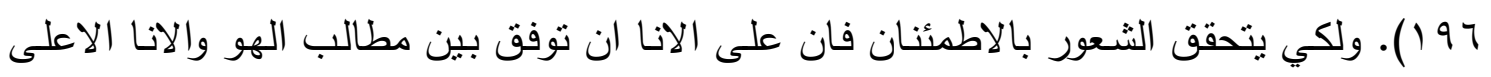

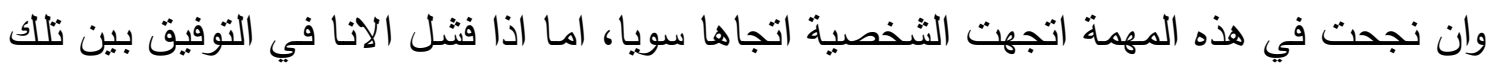
المطالب، اختل التوازن وعم الاضطراب في ثنايا الثخصية، ذلك من مهددات الثشعور بـالأمن

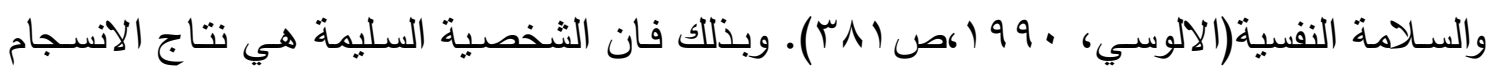

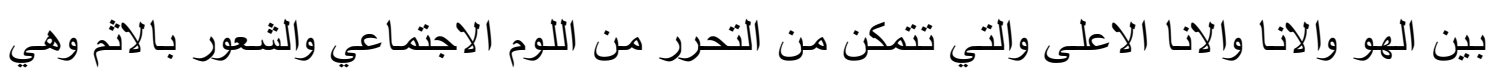

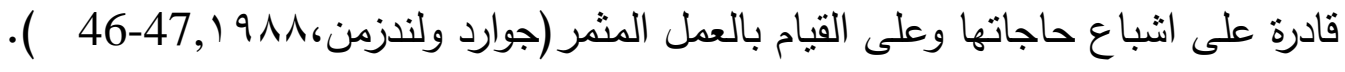


الاتجاه السلوكي

يتبع السلوكيون اتجاها اخر، حيث يركزون في وصف الثخصية على الحتمية البيئة الميكانيكة،

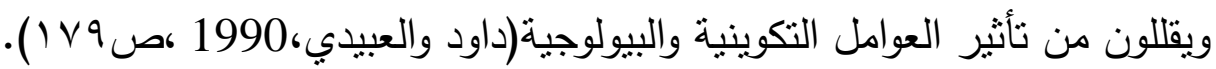

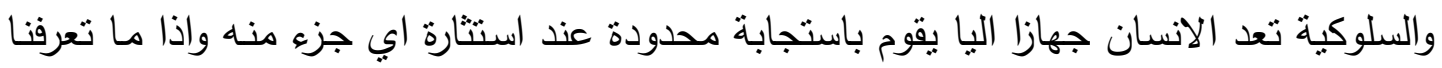
على مكوناته والمنبهات التي يتعرض اليها، استطعنا التتبؤ بالسلوك وتفسيره، طبقا الى ما اكده

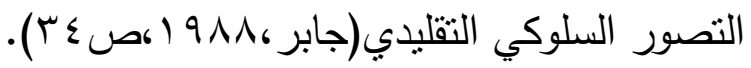
ومن الضروري معرفة ان بعض مؤيدي هذا الاتجاه يتبنى افتراض الارتباط والاقتران الفوري

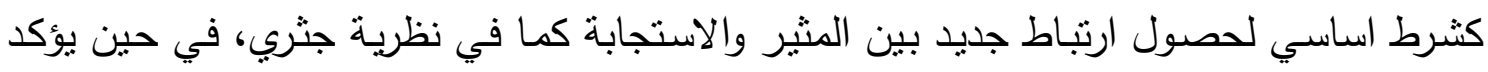

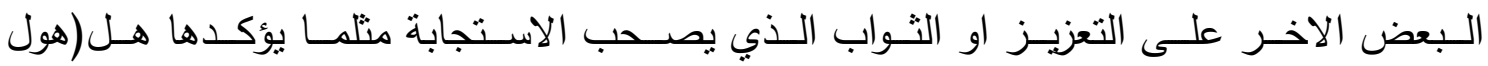

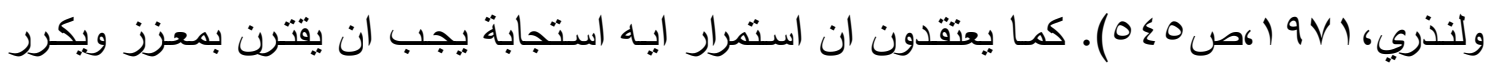

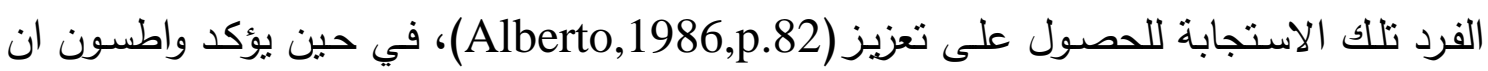

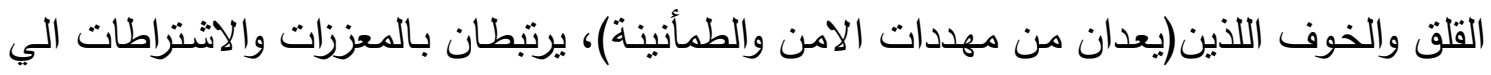

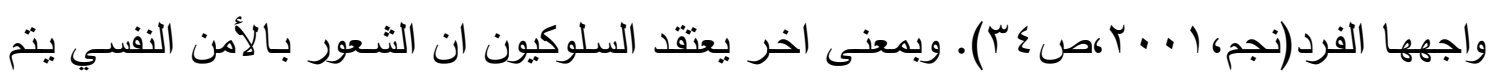

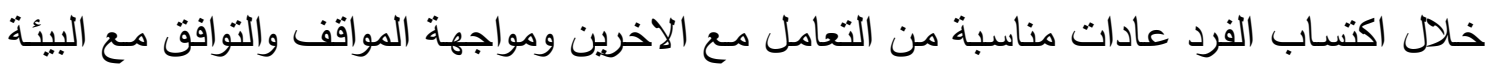

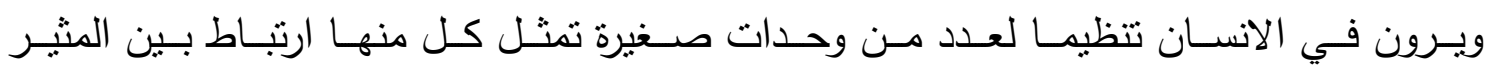
والاستجابة(Alberto,1986,p.84).

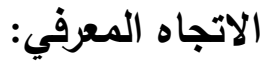

وفق هذا الاتجاه بين علم النفس الجشتالي والحركة الوظيفية حيث ركز على العمليات الادراكية والانشطة العقلية والذاكرة و بدلا من التركيز على ملاحظة السلوك الظاهر كما هو الحال لدى لدى

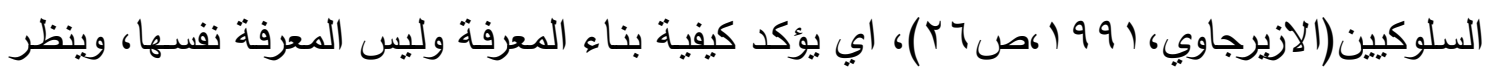

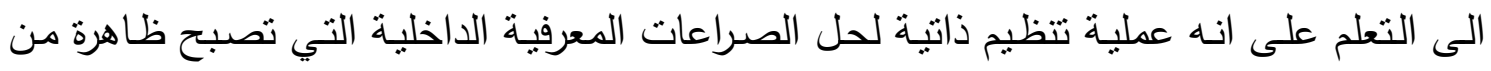

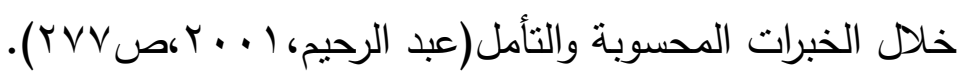

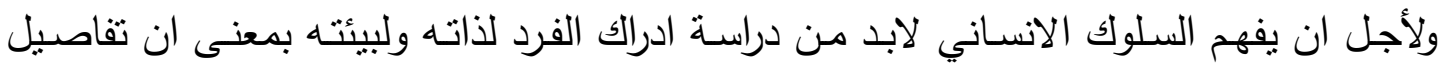

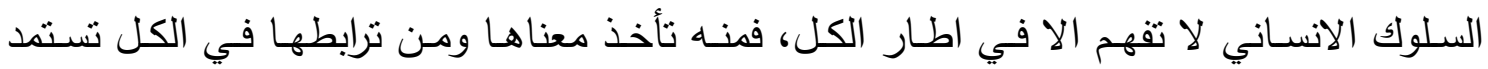

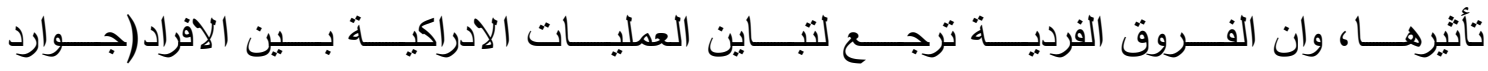

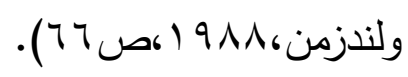

ويرى هؤلاء ان الفرد الذي يعاني من عدم الثعور بالأمن يحاول ان يحمل الاخرين مسؤولية

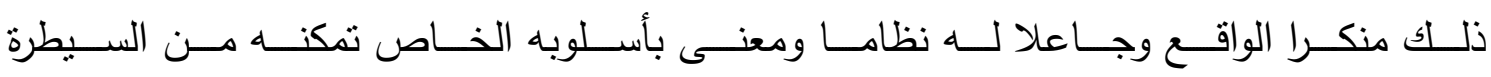

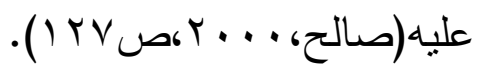




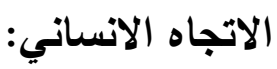

يعد ماسلو مؤسسا لعلم النفس الانساني وروجرز ، والبورت وجولد شتاين من ابرز علماء هذا

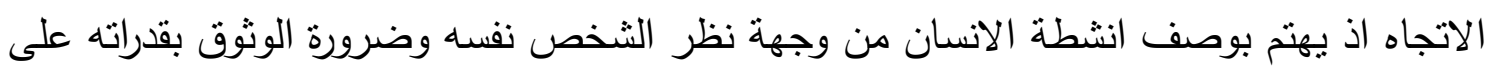

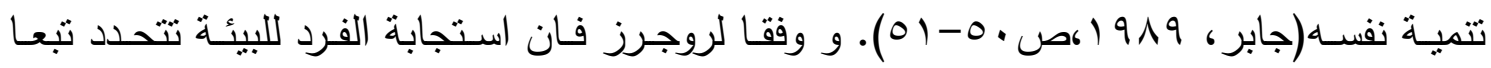

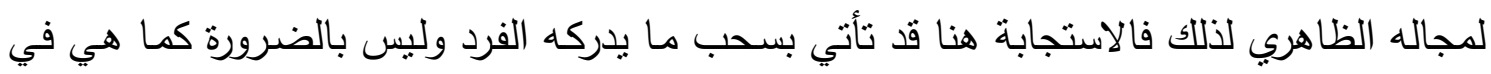

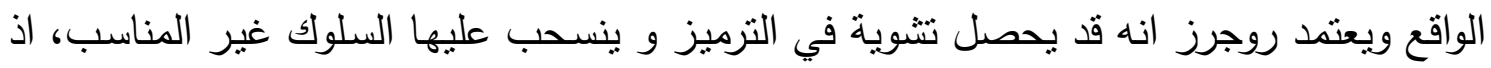

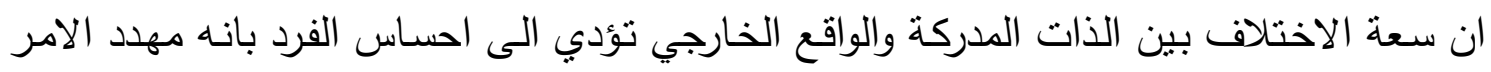

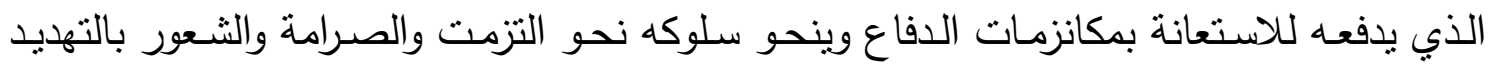

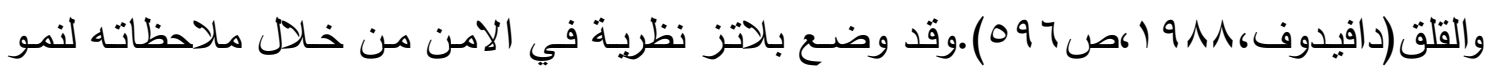

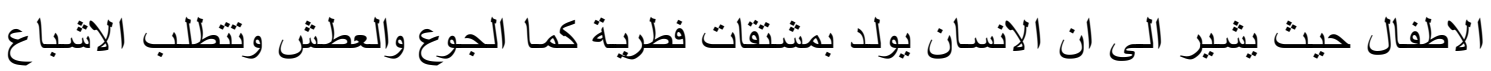

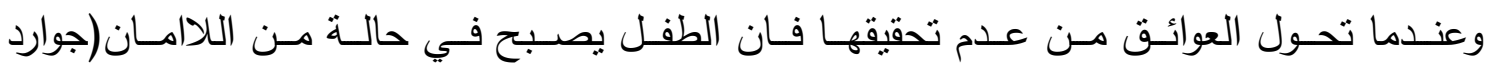

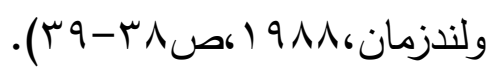

ويفترض ماسلو ان الامراض النفسية تتتج من احباط الطبيعة الانسانية وانكارها او تحويلها عن

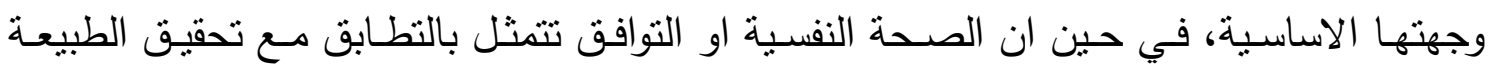

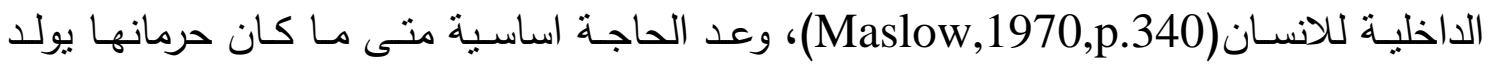

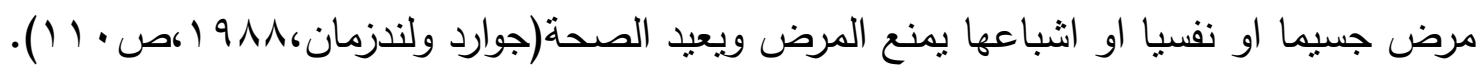

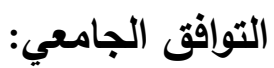

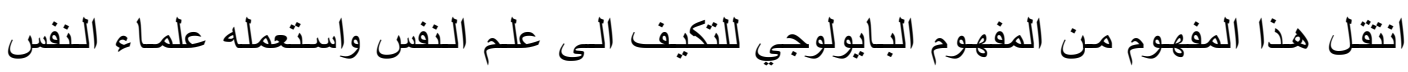

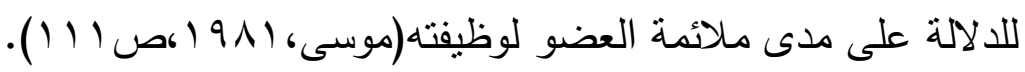
إن التوافق من اكثر المفاهيم شيوعا في علم النفس حيث استعمل للتعبير عن معان متعددة.

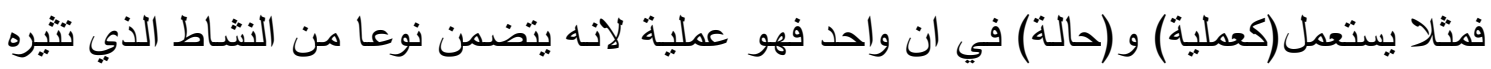

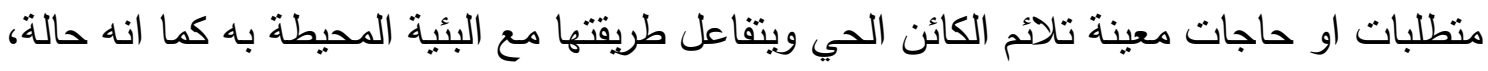

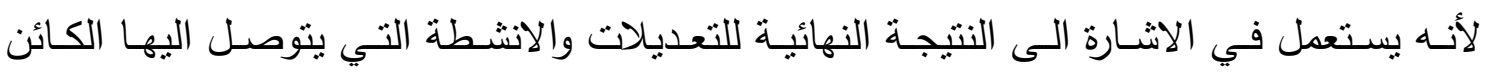

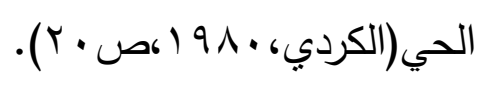

وهنا نورد بعض النظريات الي حاولت ايراد بعض التفسيرات اتجاه التحليل النفسي: يعدُ فرويد ان شخصبة الفرد تتشكل اساسـا في السنوات الخمس الاولى من حياته وان نمو

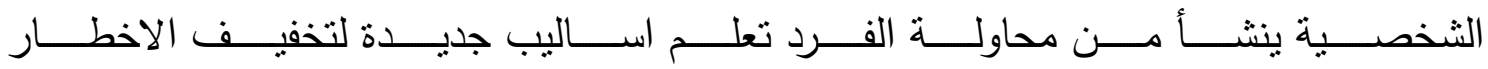

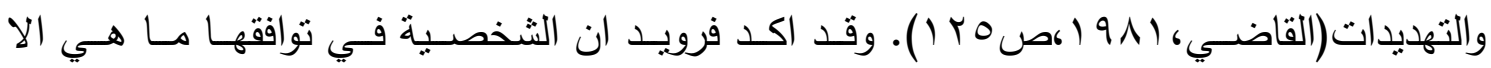


المحصلة النهائية عن امكانية تحقيق اللذة وتجنب الالم عبر الواقع الاجتماعي الذي يرسم من

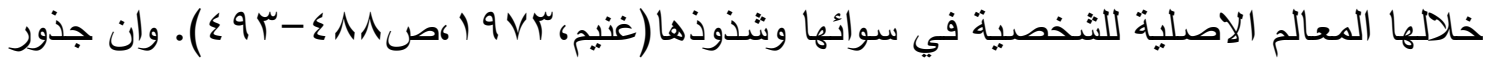

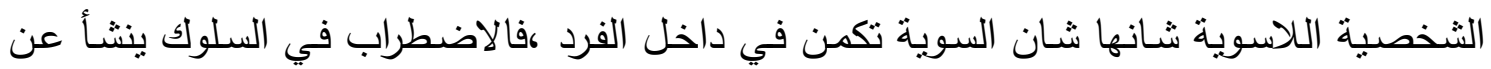
اختلال في قيام الفرد بوظائفه وان سبب الاضطراب يعود الى اختلال النوافق بين الانا والهو والانا

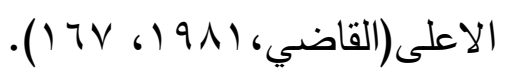

ويرى فرويد ان التوافق نادر الوجود ،لأنه يعني ان الثخصية مرت بمراحل النطور المختلفة ثم يحدث لها تتبيت عند مرحلة معينة لم تتجاوزها، وانها تملك انا قوية والتوافق عنده هو بلوغ المرحلة

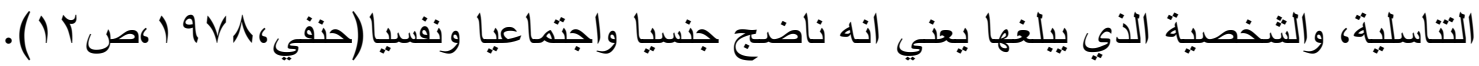

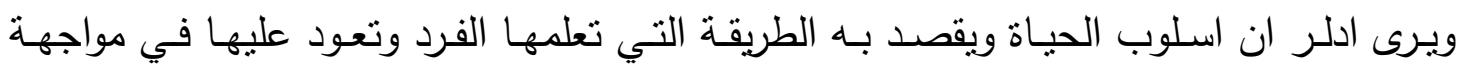

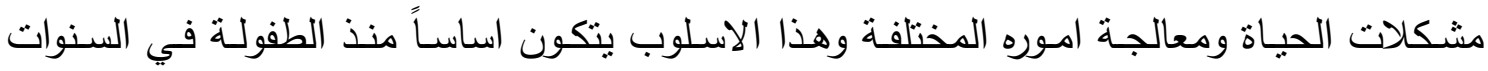

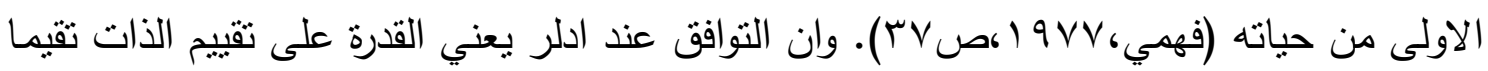

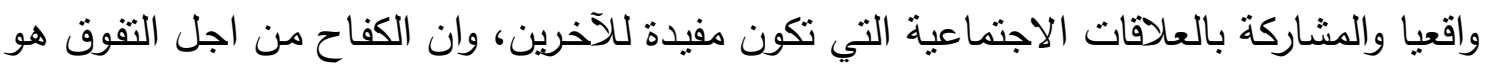
حجر زواية للتوافق (Gorlow\&walter,1968,p.120).

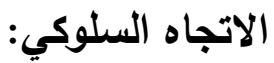
تؤكد المدرسة السلوكية ان الفرد بين الثخصية السوية والثشاذة ما هو الا الفرق بين التكيف و

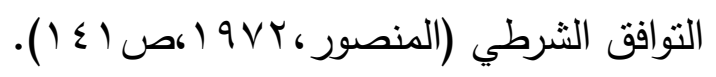

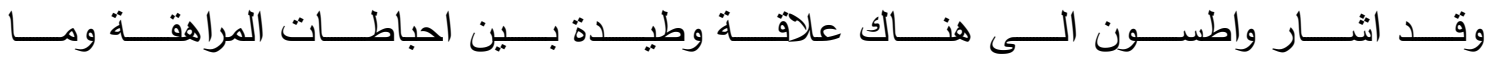

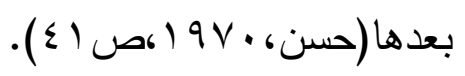

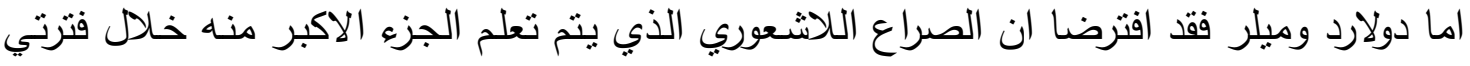
المهد والطفولـة يشكل الاسـاس لاكثر المشكلات الانفعالية شدة في مراحل الحياة التالية (هول

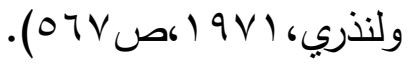
ويركز هذا الاتجاه على اهمية التعلم والخبرات التي يمر بها الفرد في عملية التوافق، وان الاثابة

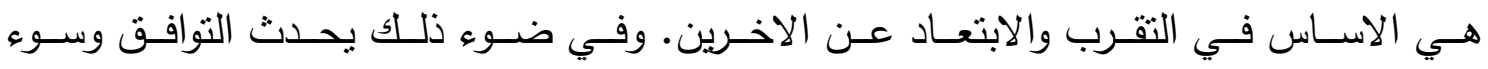
التوافق(Park,1982,p.59).

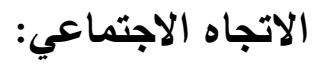
يرى اصحاب هذا الاتجاه ان التوافق هو التكيف الاجتماعي ويقصد بـه التفاعل يهدف الى الى التي

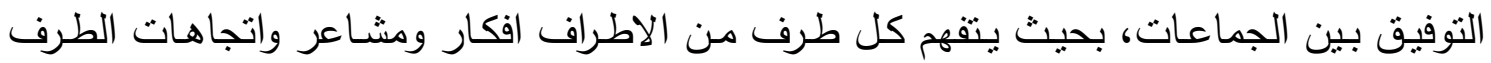
الاخر ، ليحدث بينهما تقارب يؤدي الى تحقيق مصالح مشتركة ويحدث في مجالات الحياة الاخرى 
حسب الطبقة التي يصنف منها الفرد وكذلك حسب المجتمعات وحتى الاقلية في المجتمع يتاثر

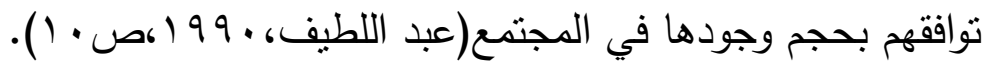

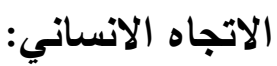
لقد اكد ماسـلو على الطبيعـة الانسـانية وانهـا تتميـز بالسـوية وكذللك الابتكاريـة والابداعيـة

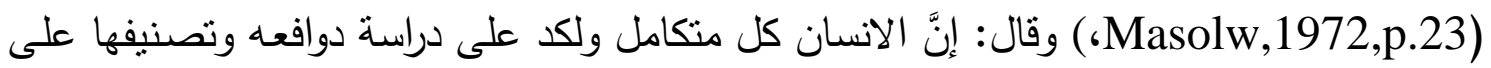

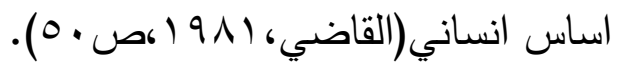
ويرى ماسـلو ان الثـخص المتوافق هو الذي يستطيع انشباع حاجاتهـ حسب اولويتها من

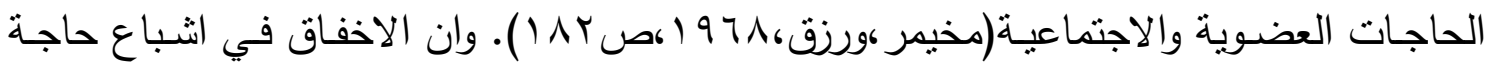

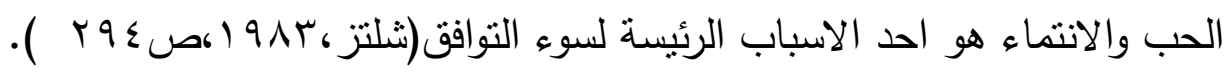
يرى اصحاب الاتجاه الانساني ان الذات المدركة تؤثثر في ادراك الفرد للعالم المحيط بـ تقابلها

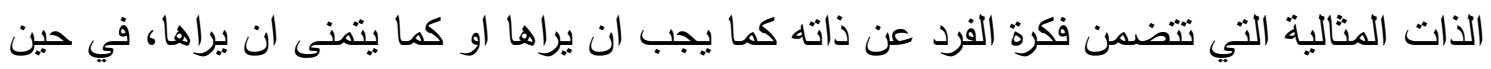

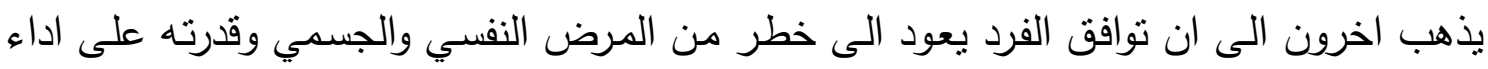

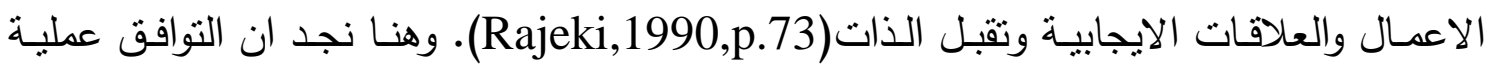
مركبـة من عنصرين اساسين هـا الفرد ودوافعـه وحاجاته وتطلعاته والاخر هو البيئة الطبيعيـة

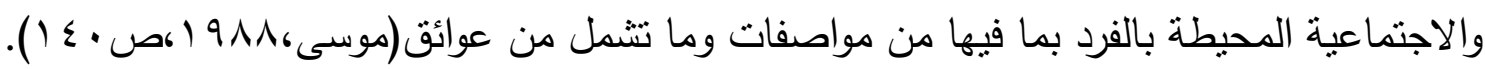

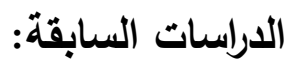
اولاً/ الدراسات التي تناولت الامن النفسيّ:

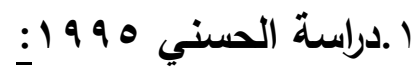

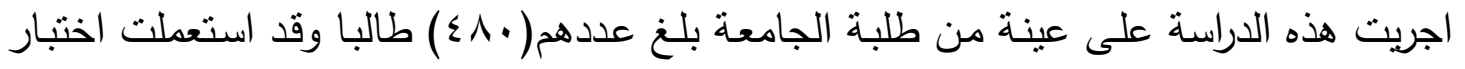

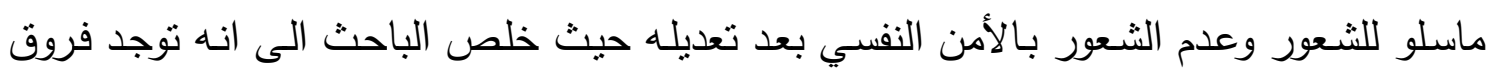

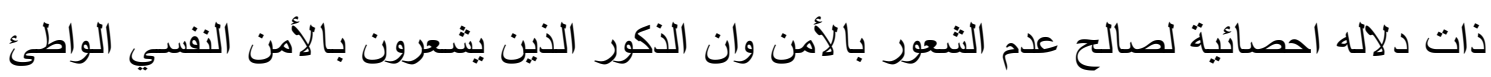

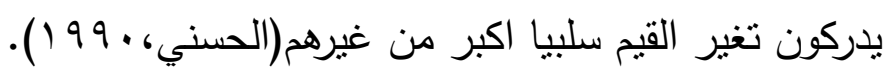

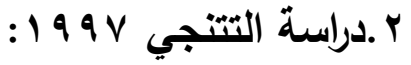
اجريت هذه على عينـة من طلبة الجامعة بلغت ( • ) طالبا حيث طبق عليهم اختبار ماسلو

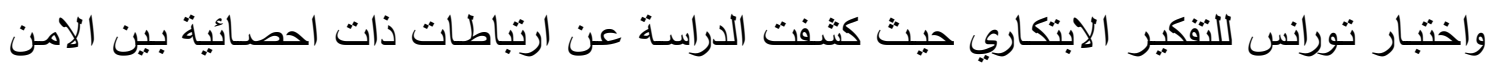

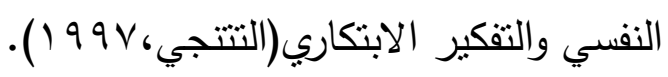

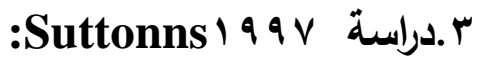

اجريت هذه الدلالة عل عينة من(·1 (1) مدرسا ومدرسة حيث طبق عليهم اختبار ماسلو ومقياس

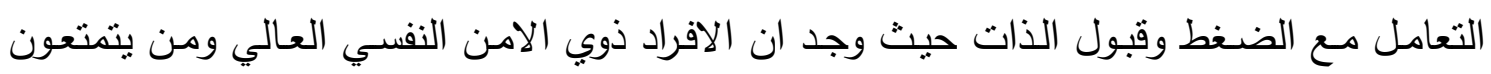


بقبول الذات يبدون تعامل افضل مـع الضغوط التي تواجههم في حين يلجاء الافراد ذوب الامن النفسي المنخفض الى احلام اليقظه وتناول الكحول(Suttons,1997).

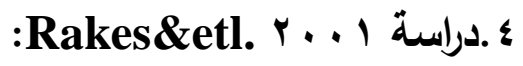

اجريت هذه الدراسة علىى عينة من( آل ا ) من اعضاء الهيئات التدريبية حيث طبقت عليهم

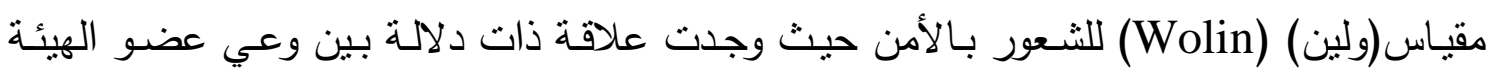

التعليمية بسلوكهم وشعوره بالأمن النفسي تبعا للجنسين ولصالح الذكور (Rakes\& etl, 2001). ثانياً/ الاراسات التي تناولت التوافق الجامعي:

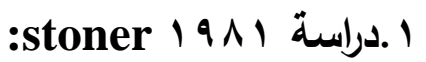

اجريت هذه الدراسة على عينة من( •00) طالبا وطالبة حيث طبق اختبار رضا الطالب عن

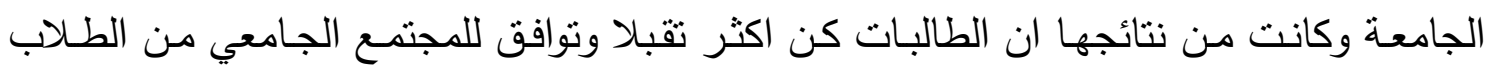

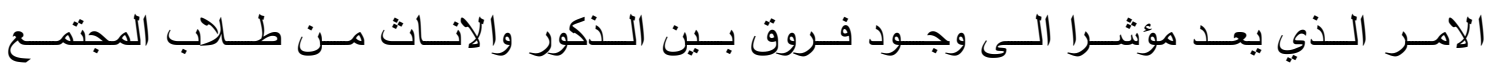
الجامعي(Stoner,1981)

\section{: Harris \& anton 1910 دراسة}

اجريت هذه الدراسة على عينة من(ب07) طالبا وطالبة واستعملت قائمة الحاجات كمقياس لمعرفة الفروق في الحاجات لدى كل من الطلاب والطالبات من افراد العينة واظهرت نتائج الدراسة فروق ذات دلالة بين الذكور الاناث لصالح الذكور (Harris \&Anton,1985).

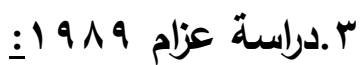
اجريت هذه الدراسـة على عينـة من (9 ـ 9) طالبـا وطالبـة واستخدام فيها مقياس الاغتراب

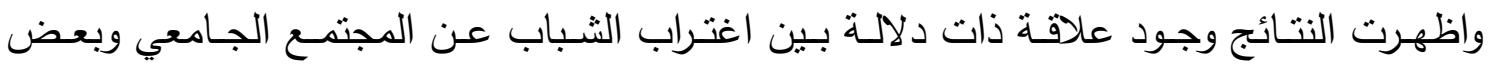

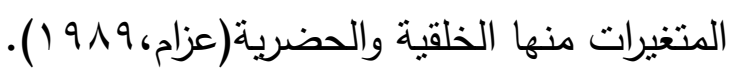

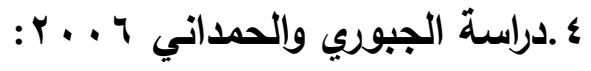

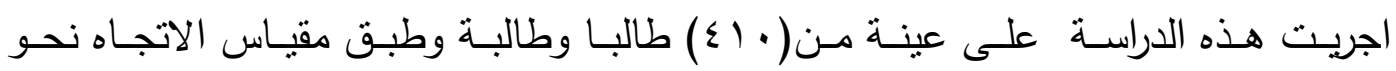

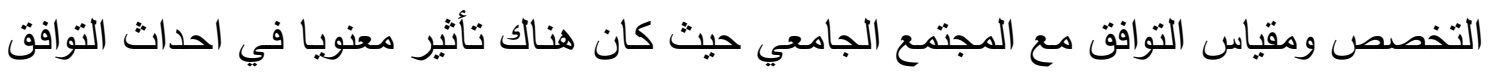

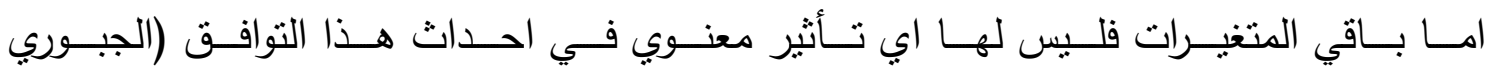

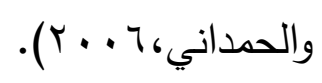

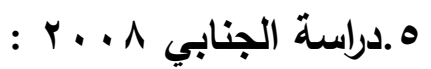

اجريت هذه على عينـة من ( . (0) طالبـا وطالبـة طبق عليهم مقياس استراتيجيات التكيف مقياس للتوافق الجامعي حيث توصلت الى ان طلبة الجامعة يمليون الى المواجهة والتحدي بالنسبة 
لاستراتيجيات التكيف وانهم متوافقين مسع بيئتهم رغم الظروف القاهرة ولم يكن هناك فروق بين

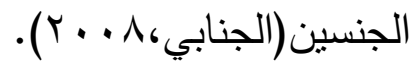

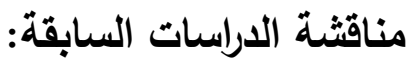
أولاً/ مناقشة دراسات الأمات الامن النفسيّة: إنَّ اغلب هذه الدراسات طبقت مقياس ماسلو والذي يقيس الثُعور وعدم الثعور بالأمن النفسي

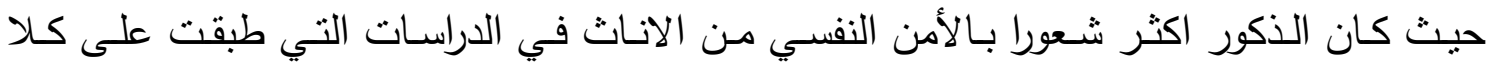

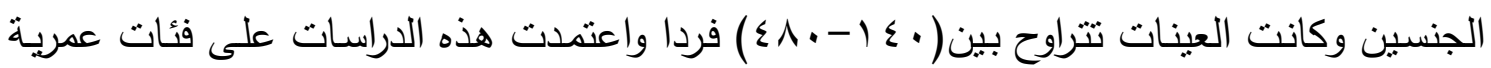
مختلفة متتوعة اما هذه الدراسة فقد تتاولت طلبة الجامعة حيث ان الدراسات التي تتاولت هذه كانت

ثانياً/ الدراسات التي تناولت التوافق الجامعيّ: إن هذه الدراسات طبقت مقاييس واختبارات منتوعة وكانت العينات تتراوح بين( 07 ب- ـ 9)

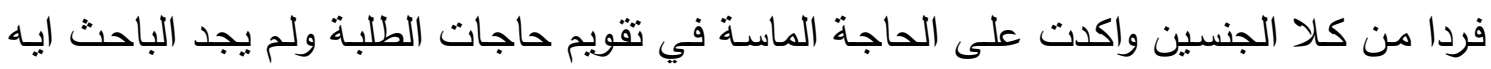

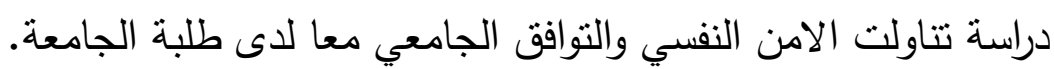
منهج البحث واجراء|ته:

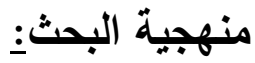

إن المنهج المستعمل في البحث الحالي هو المنهج الوصفي المسحي والذي سعى الى تحديد الوضع الحالي للظاهرة المدروسة، ومن وصفها، وبالنتيجة يعتمد دراسة الظاهرة على ما توجد عليه

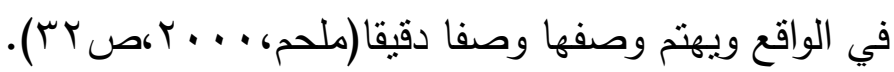

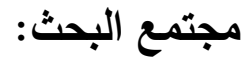
يشتمل مجتمـع البحث الحالي طلبة الدراسـة الاولية الصباحية في الجامعة المستتصرية/كلية

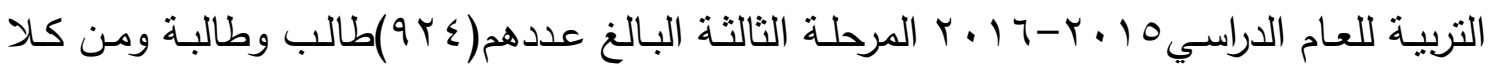

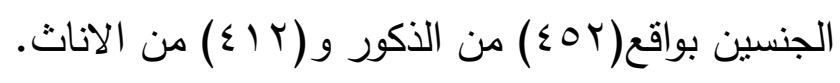

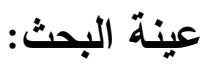

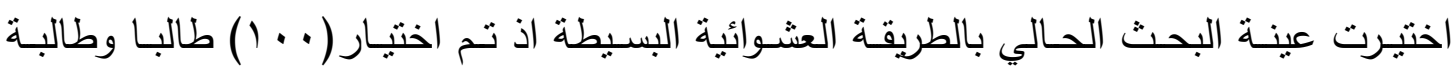
بواقع • (0) ذكور و (0) اناث من طلبة الجامعة المستصرية/كلية التربية المرحلة الثالثة والجدول رقم( (1)يوضح ذلك.

جدول( ) ائح عينة البحث

\begin{tabular}{|c|c|c|}
\hline العدد الكلي & الاناث & الأكور \\
\hline $1 \ldots$ & 0. & 0. \\
\hline
\end{tabular}




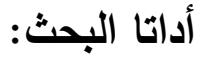

بغية تحقيق اهداف البحث تطلب استعمال اداتين هما:

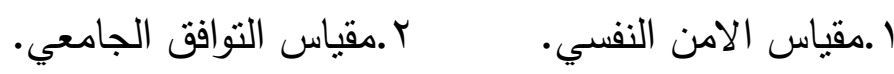

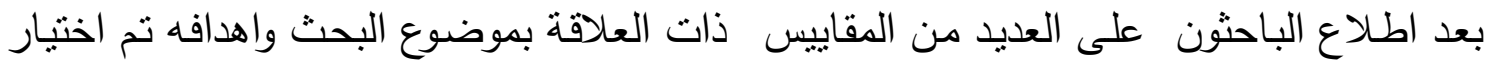

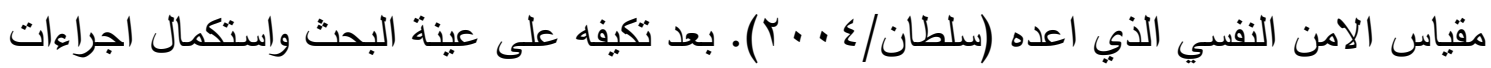

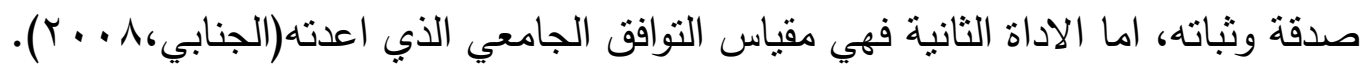

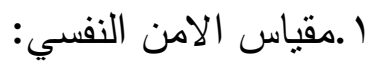

$$
\text { وصف المقياس الذي اعده(سلطان، ع . ب. ب): }
$$

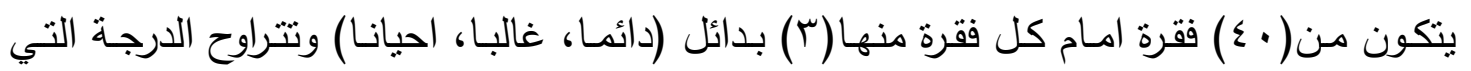

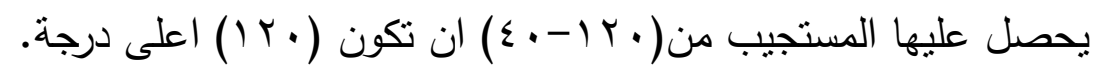
تكيف المقياس:

بما ان فقرات المقياس الاصلي هي معده اصلا لعينة من طلبة المرحلة الاعدادية ،الاعدادية لذللك توجب تغير وتعديل صياغة الفقرات وحذف الفقرات غير المناسبة والتي لا يتلائم تعديلها

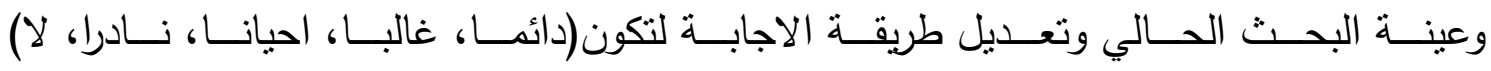

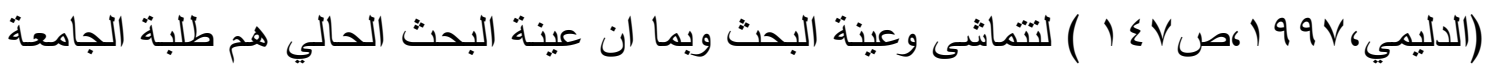

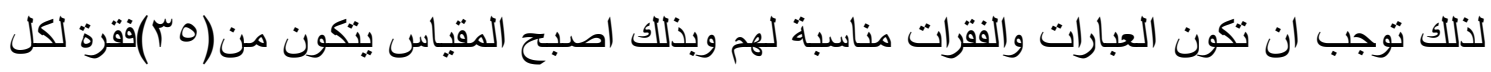

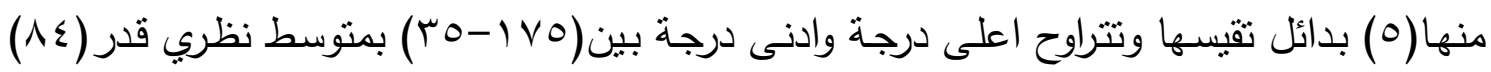
درجة لاحظ الملحق( (1) المقياس بصورته النهائية. التجربة الاستطلاعية:

استهدفت التعرف على مدى وضوح المقياس من حيث الصياغة المعنى ومدى فهم المستجيب اللفقرات والبدائل الاجابة والزمن المستغرق لذلك ولتحقيق ذللك تم تطبيق المقياس على(· ب) طالبا

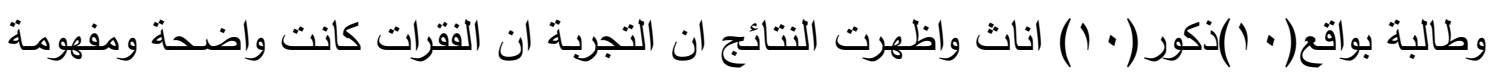

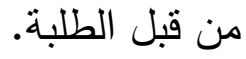

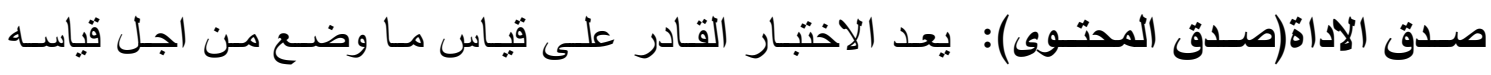

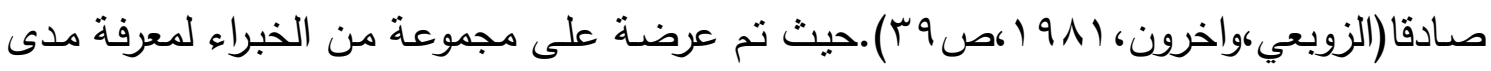
صلاحيته المقياس لقياس ما وضع لأجل قياسه .

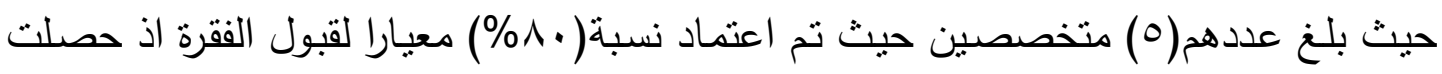

جميعها على اتفاق الخبراء ملحق رقم(r). 


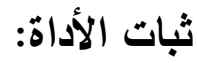

يعدُ الثبات احد مؤشرات التحقق من دقة المقياس واتساق فقراته في قياس ما يجب قياسه، اذ ان

الثبات يشير الى درجة استقرار الاختبار والتتاسق بين اجزائه(Anastasi, 1976,p,110).

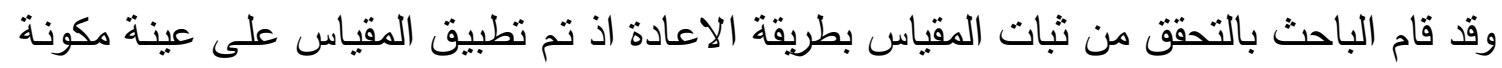

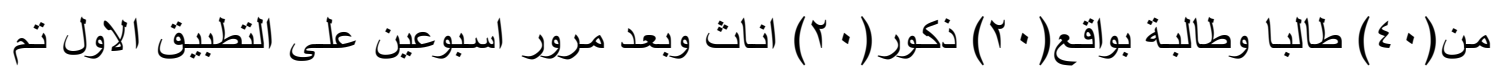

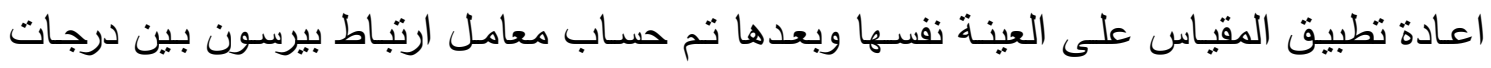

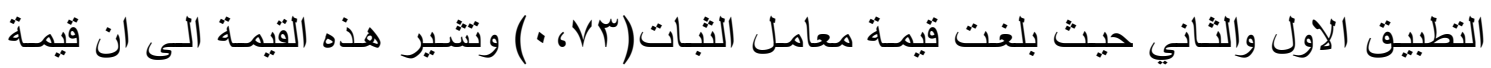

$$
\begin{aligned}
& \text { الثبات كانت جيدة(عيسوي، \& ل9 (،صوهم). } \\
& \text { مقياس التوافق الجامعي: }
\end{aligned}
$$

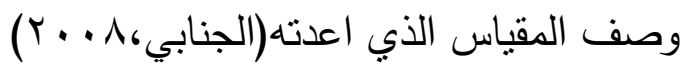

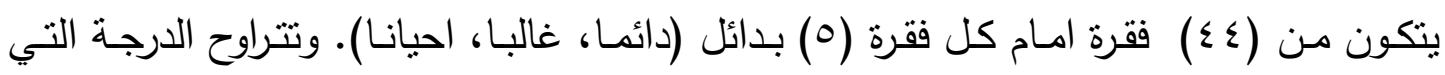

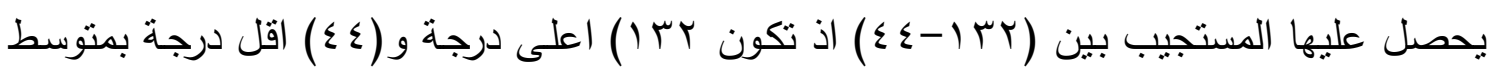

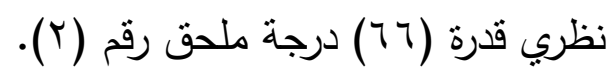
صدق الأداة (صدق المحتوى):

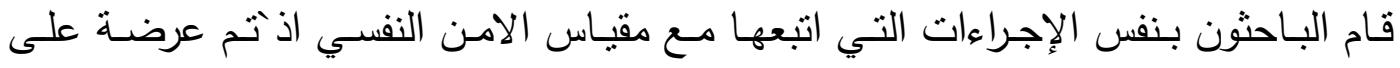

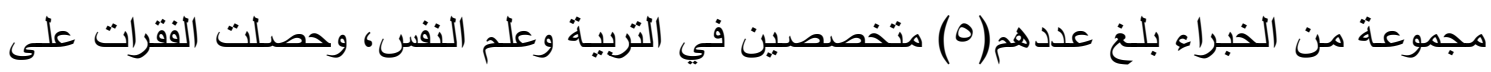
نسبة اتفاق(•^\%) وهذا يعد معيار لقبول الفقرة لاحظ الملحق رقم(؟).

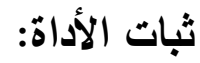

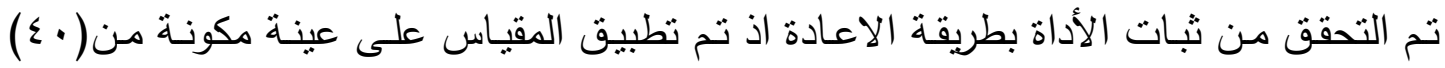

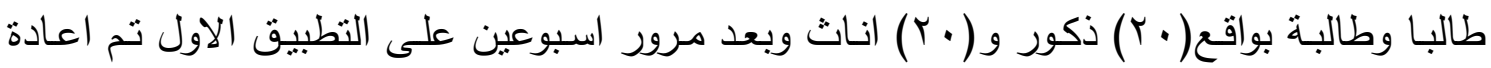
تطبيق المقياس على نفس العينة، وبعدها تم حساب معامل ارتباط بيرسون بين درجات التطبيق

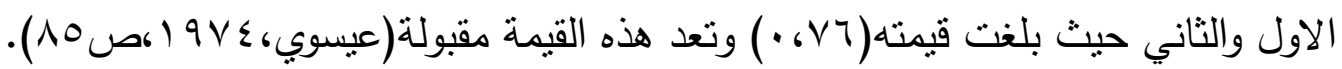

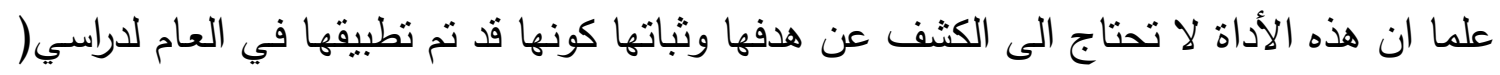

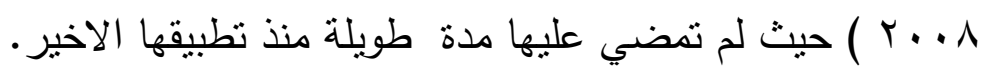

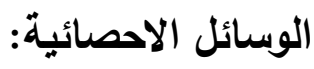

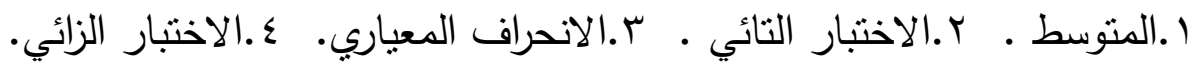

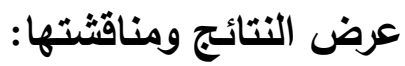
فيما يأتي عرض نتائج البحث التي نم التوصل اليها وفق الاهداف التالية: 
ا ـالتعرف على مستوى الامن النفسي لدى طلبة كلية التربية في الجامعة المستتصرية لتحقيق هذا الهدف تم جمـع البيانات التي تم الحصول عليها من عينة البحث الاساسية والبالغة( . ( ) طالبا

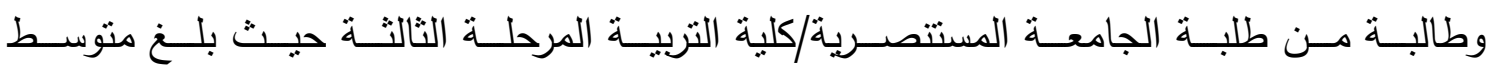

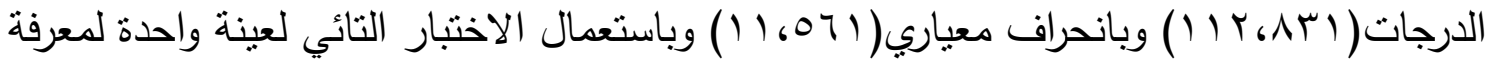

الفرق بين المنوسط الحسابي والمتوسط النظري كما في الجدول رقم(r)

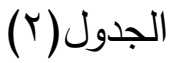

خلاصة الاختبار التائي لدلالة الفرق بين المتوسط المحسوب والمتوسط النظري لمتغير الامن

\begin{tabular}{|c|c|c|c|c|c|c|c|}
\hline \multirow[t]{2}{*}{ الدلالة } & نائية & القيمة & \multirow{2}{*}{ النظريط } & \multirow{2}{*}{ المعياري } & \multirow{2}{*}{ الحستوسي } & \multirow[t]{2}{*}{ العدد | ل العد } & \multirow[t]{2}{*}{ المتغير } \\
\hline & لجدولية & المحسوبة & & & & & \\
\hline .60 & 1.97 & rl.Vo & $\Lambda \varepsilon$ & 11.071 & IIr.ATI & $1 \cdots$ & الأمن النفسي \\
\hline
\end{tabular}

وتتـير نتائج الجدول(Y) الى وجـود فرق دال بين المتوسط الحسـابي المحسوب والمتوسـط

النظري لمتغير الامن النفسي ولمـا كان الفرق لصـالح المتغير المحسوب فان ذلك يدل على ان مستوى الامن النفسي لاى افراد العينة بنحو عام عال وان القيمة التائية المحسوبة كانت اكبر من الجدولية عند مستوى(0 • ، • ) وبدرجة حربـة(91) ، وهذا يعكس مدى السـلامة النفسية والطمأنينة النفسية التي يشعر بها الطالب الجامعي بالرغم من الظروف الصعبة التي يعيشها البلد ، ولعل ذلك يفسـره أن السـوك الإنسـاني يعد مـن محددات التفاعل بين طبيعـة الفرد والموقف الذي يوجد بـه فالأداء يظهر نتيجة للتفاعل بين الدوافع الداخلية والدوافع الخارجية التي تأتي في مقدمتها الشعور بالطمأنينة والأمن النفسي، فقد أثنار بولبي ان الصحة النفسية الايجابية هي الأساس في بناء الأمن النفسي والطمأنينة النفسية التي هي منطلق الانفتاح على الآخرين (الدليم ، 0 . . ب) ، وبذلك نجد مؤشرات الصحة النفسية لاى الطالب الجامعي من خلال ارتباطها بالأمن النفسي ولعل هذا يتسق

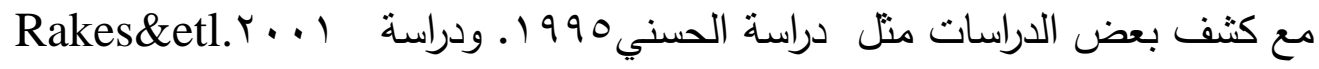
r.معرفة الفرق في مستوى الامن النفسي تبعا لمتغير الجنس،ولتحقيق هذا الهدف تم جمع البيانات الـى تم الحصـول عليهـا مـن عينـة البحـث الاساسية والبالغـة( . . ( ) طالبـا وطالبـة قـام الباحـث باستعمال الاختبار التائي لعينتين مستقلتين كما في الجدول(r). جدول(r)

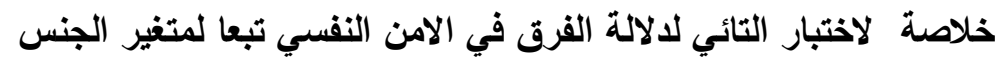

\begin{tabular}{|c|c|c|c|c|c|c|}
\hline الدلالة & القيمة|لتائية الجدولية & المحسوبة & الانحراف المعياري & المتوسط الحسابي & العدد & الجنس \\
\hline دالةعند & 1.97 & $r .0 \wedge 1$ & $11,1 Y 1$ & 11Y600. & 0. & الأكور \\
\hline. .00 & & & r.oN1 & 196911 & 0 . & الاناث \\
\hline
\end{tabular}


وتتشير النتائج في الجدول(؟) الى وجود فروق ذات دلالـة احصـائية عند مسنتوى(0.، •)

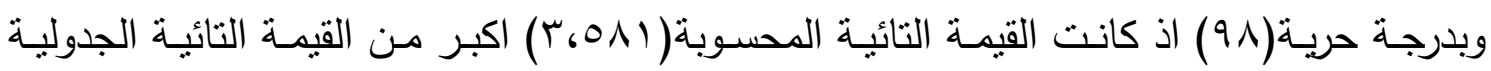

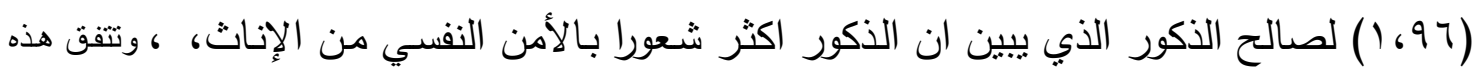

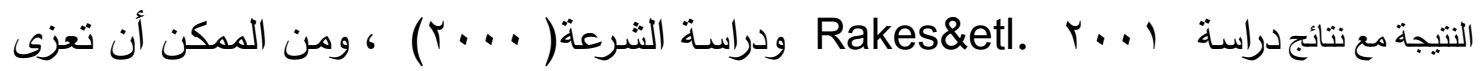

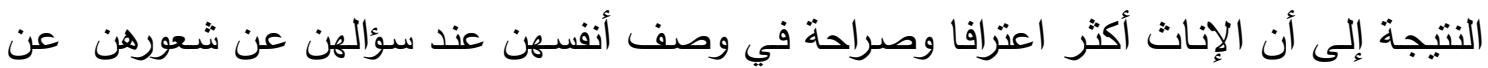
(Perlman \& Peplau, 1998)، الامن النفسي التي يعاني منها، وهذا ما يؤكده بيرلمان وبيبلان الإنيان

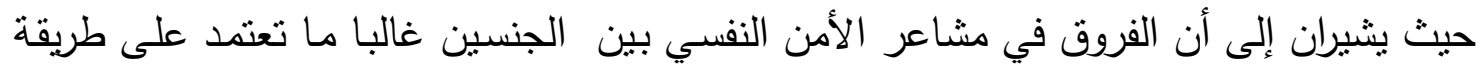

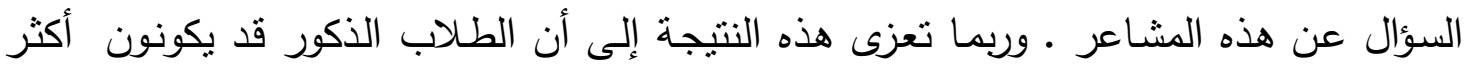

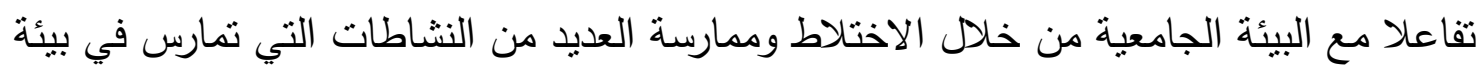

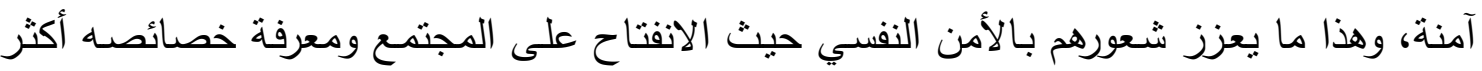

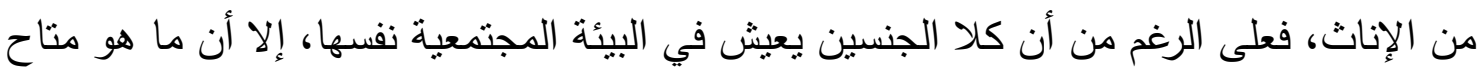

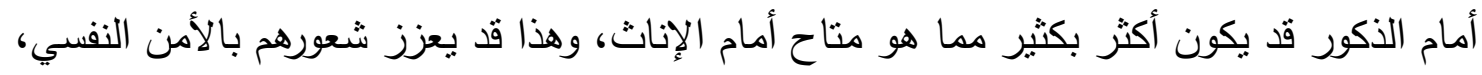

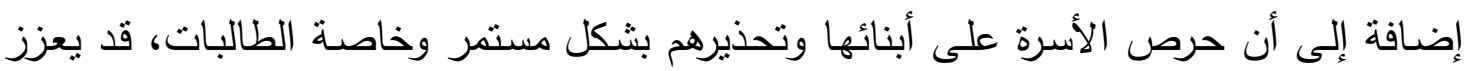
لايهن الإحساس بعدم الثعور بالأمن النفسي. r.التعرف على مستوى التوافق الجامعي لدى عينة البحث، لتحقيق هذا الهدف تم جمع البيانات

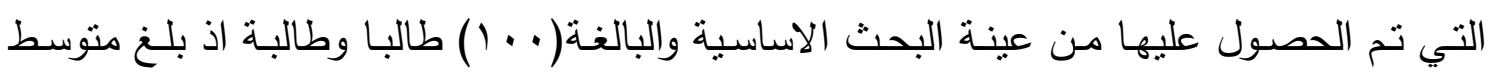

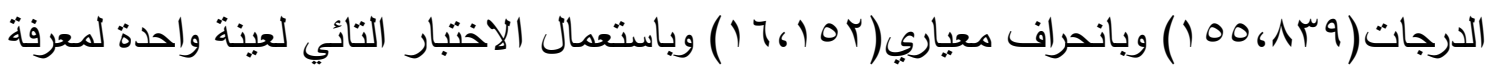

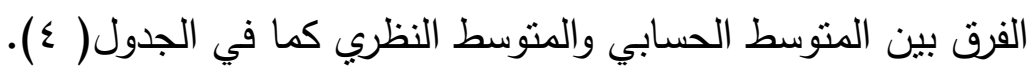

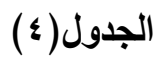

خلاصة الاختبار التائي لدلالة الفرق بين المتوسط الحسابي والمتوسط النظري لمتغير التوافق الجامعي

\begin{tabular}{|c|c|c|c|c|c|c|}
\hline الدلالة & القيمةالتائية & المحسوبة & الالحعراف & الحستوسطي & العدد & المتغير \\
\hline داله عند ه .. . & 1.97 & $r \leqslant, r \leqslant 1$ & $19.10 Y$ & $100 ، \wedge r q$ & $1 \ldots$ & التو افقت الجامعى \\
\hline
\end{tabular}

وتتنير النتائج في الجدول(ع) ال وجود فرق دال بين المتوسط الدحسوب والمتوسط النظري لمتغير التوافق الجامعي ولمـا كان الفرق للمتغير المحسوب فـان ذلك يعني ان مستوى التوافق الجامعي لاى افراد العينة بنحو عام هو عال وان القيمة التائية الدحسوبة اكبر من القيمة الجدولية

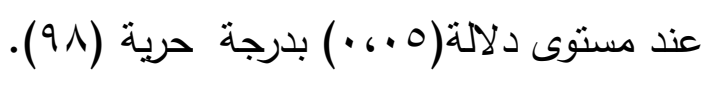

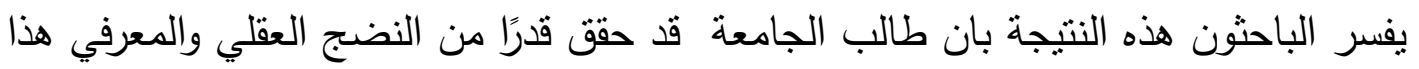

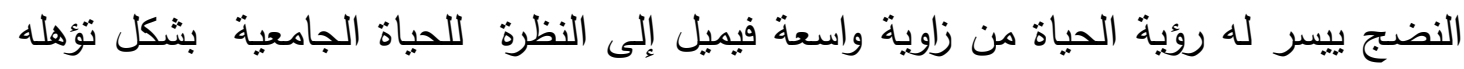

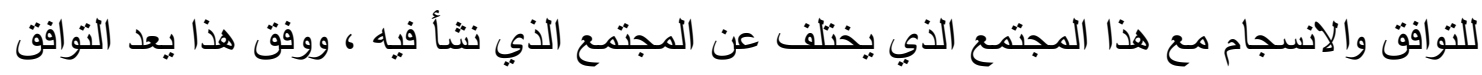


النفسي والاجتماعي مظهرًا رئيسيًا من مظاهر الصحة النفية للطالب الجامعي والذي يتضمن قدرته على تغيير سلوكه وعاداته عندما يواجه موقفًا جديدًا أو مشكلة مادية أو اجتماعية أو صراعًا

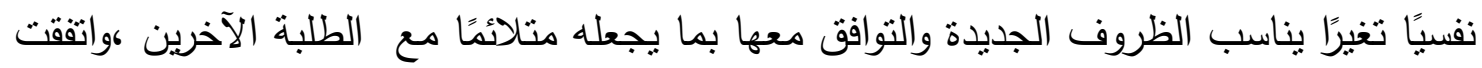
نتيجة هذه الدراسة مع دراسة احمد ( ب99 1) التي توصلت إلى وجود علاقة ايجابية وذات دلالة

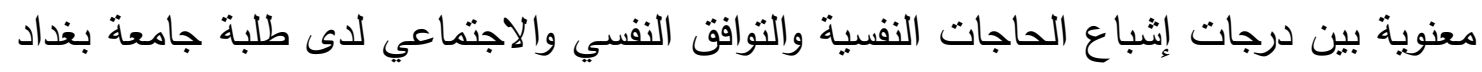
بغض النظر عن الجنس والتخصص والمرحلة ، إلا أنها اختلفت مع دراسة جابر ( 990 (1) التي أثنارت إلى أن طلبة جامعة بغداد لا يتمتعون بتوافق نفسي اجتماعي حيث حقق أفراد العينة درجات واطئة على مقياس التوافق النفسي والاجتماعي. ع .معرفة الفرق في مستوى التوافق الجامعي لمتغير الجنس ولتحقيق هذا الهدف تم جمع البيانات التهات

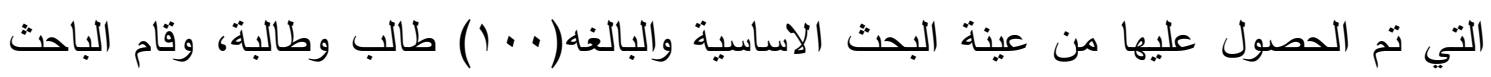

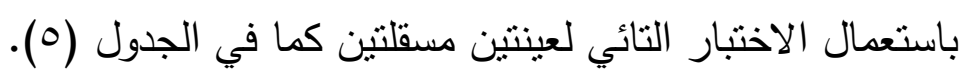

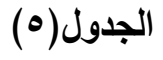

\begin{tabular}{|c|c|c|c|c|c|c|}
\hline الدلالة - مالة & التائية & المحسوية & الانحراف المعياري & المتوسط الحسابي & العدد ال العد & الجنس \\
\hline \multirow[t]{2}{*}{ دالةّعند ه •، . } & \multirow[t]{2}{*}{1.97} & \multirow[t]{2}{*}{$.6 \% 91$} & IV.ork & $100 . \mathrm{V} 11$ & 0. & الأكور \\
\hline & & & $19, Y Y \leqslant$ & $100,4.9$ & 0. & الاناث \\
\hline
\end{tabular}

خلاصة الاختبار التائي لعنتين مستقلتين تبعا لمتغير الجنس لمتغير التوافق الجامعي

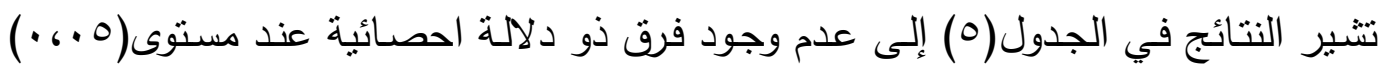

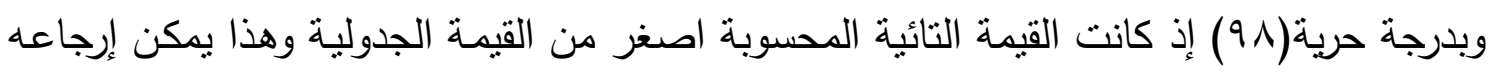

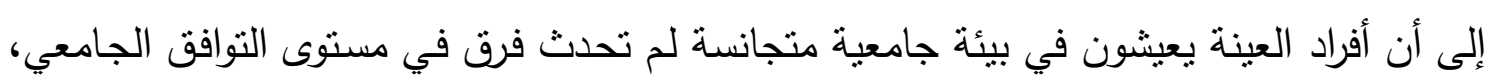

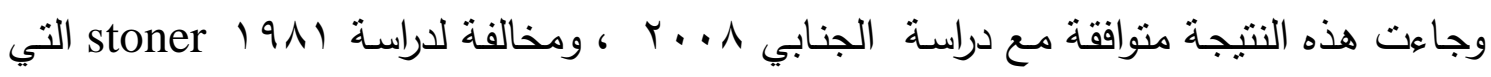

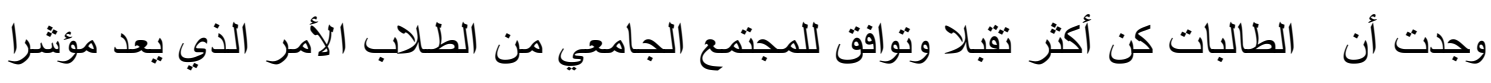

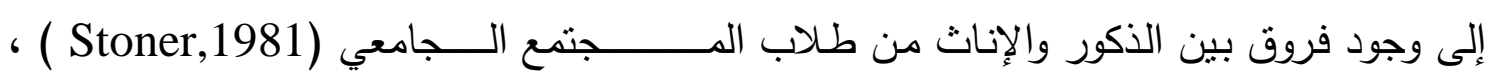

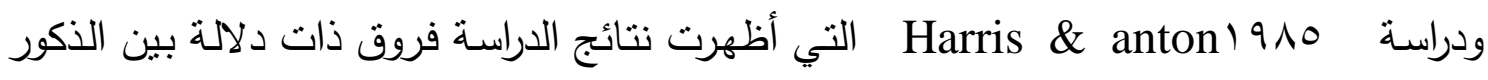
الإناث لصالح الذكور (Harris \&Anton,1985).

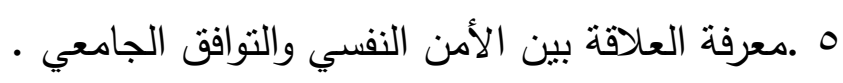

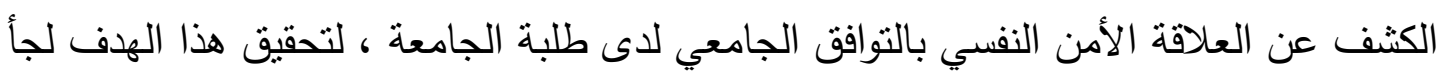

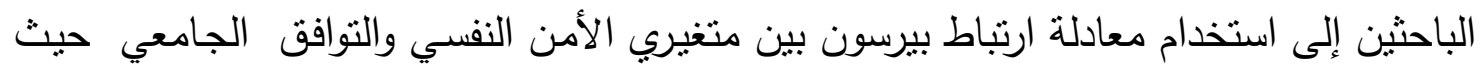

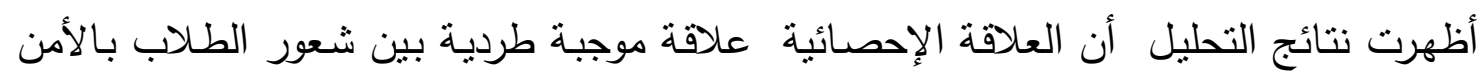
النفسي وتوافقهم الجامعي ، والجدول ( 1 ) يوضح ذللك. 
جدول (7) (7)

الاختبار التائي لمعنوية معامل الارتباط بين متغيري الأمن النفس والتوافق الجامعي.

\begin{tabular}{|c|c|c|c|c|}
\hline مستوى اللالالة & الجدولية الجية & المحسوبة & معامل الارتباط & العينة \\
\hline دال عند مستوى 1.. & 1.78 & $0 . T r$ & .90 & $1 \cdots$ \\
\hline
\end{tabular}

ويمكن تفسير هذه النتيجة على أن الأمن النفسي من حياة الطالب الجامعي ومن حياة أي فرد آخر لا يمكن عزله عن الجوانب الأخرى في شخصية الإنسان وخاصة الجانب الاجتماعي وان الأن الهن

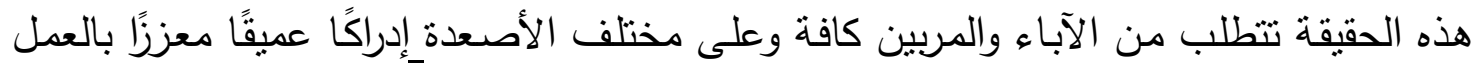

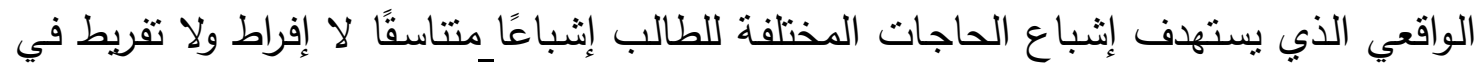
جانب من جوانب الثخصية .كما تتقق هذه النتيجة مع ما ذهب إليه ماسلو في مبدأين أساسيين

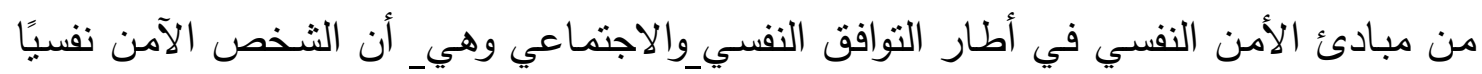

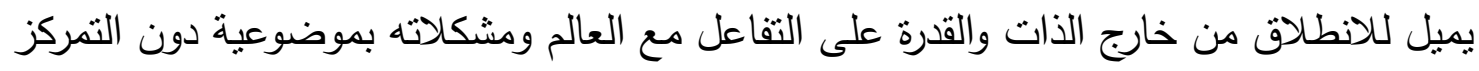

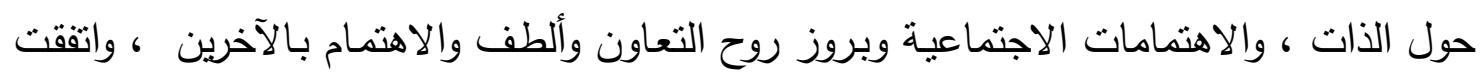

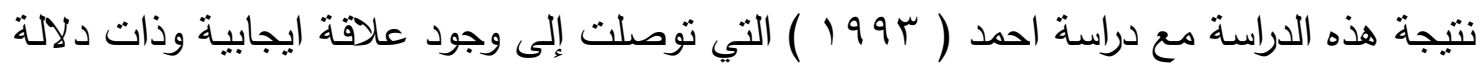
معنوية بين درجات إثباع الحاجات النفسية والتوافق النفسي والاجتماعي لدى طلبة جامعة بغداد النداد بغض النظر عن الجنس والتخصص والمرحلة.وكذلك دراسة التي أكد على وجود علاقة ايجابية بين الأمن النفسي والتوافق النفسي والاجتماعي لاعى طلاب معهز إعداد المعلمين .

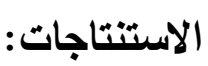
ا.إن طلبة الجامعة يتمتعون بمستوى جيد من الثـعور بـالأمن النفسي بـالرغم من كل الظروف دلف المحبطة بهم. r.إن الذكور هم اكثر شعورا بالأمن النفسي من الاناث وربما يعود ذلك لأسلوب نشأتهم والاختلاف في التعامل بين الذكور والاناث. r.اظهر طلبة الجامعة مستوى عال من التوافق الجامعي وربما يعود ذلك لكونهم في مرحلة متقدمة من الدراسة ومستوى جيد من النضج. ع.عدم توافر فروق في التوافق الجامعي بين الذكور والاناث وربما يعود ذللك الى انهم يعيشون في بيئة جامعية متجانسة. ه. إن العلاقة بين الأمن النفسي والتوافق الجامعي علاقة موجبة طردية بين شعور الطلاب بالأمن النفسي وتوافقهر الجامعي.

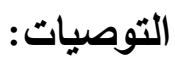


في ضوء البحث الحالي واستتناجاته يوصى الباحثون بقيام المؤسسات التعليمية باستثمار هذه النتائج لتحسين العملية التعليمية وذلك بتقوية العلاقة بين الطالب والمؤسسة لتحقيق الهلف من وراء

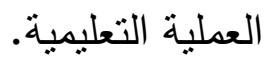
المقترحات: - (المات ا.جراء دراسة تشتمل مراحل دراسية اخرى. r.تكيف مقياس التوافق الجامعي مع طلبة المعاهد. r.اجراء دراسة تكثنف عن العلاقة بين الامن النفسي وبعض المتغيرات مثل (تحقيق الذات).

\section{المصادر:}

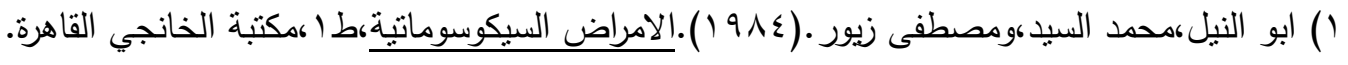

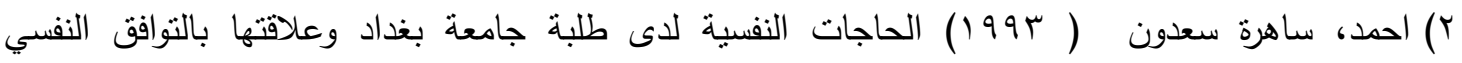

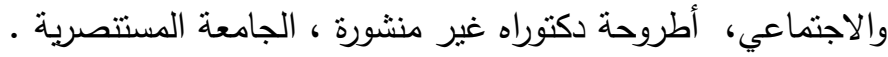

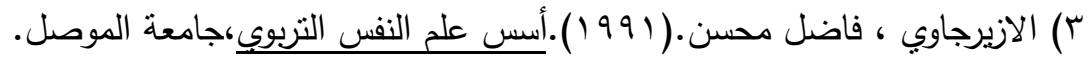

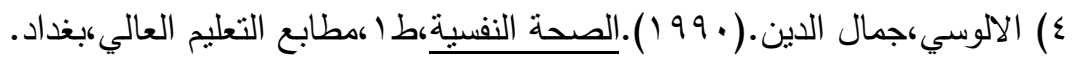

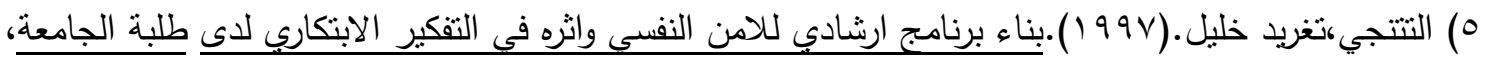

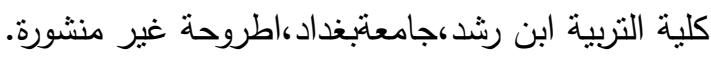

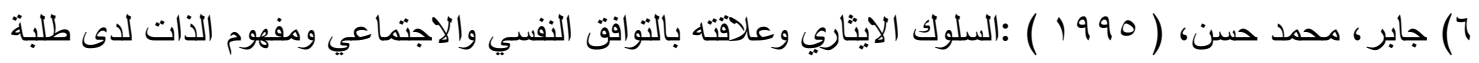
جامعة الموصل، رسالة ماجستير غير منشورة ، جامعة الموصل، كلية التربية.

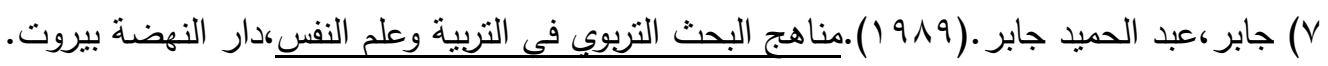

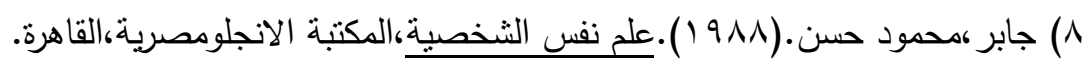

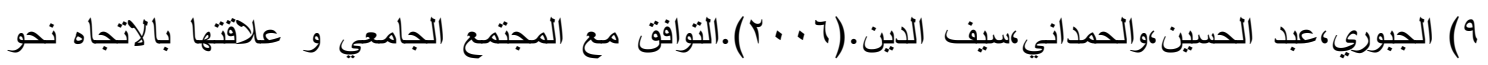

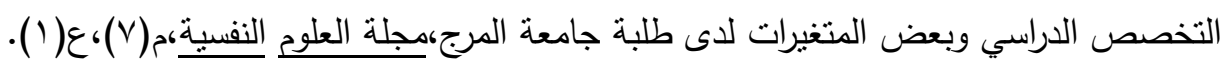

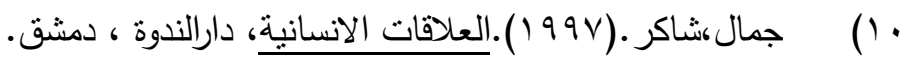

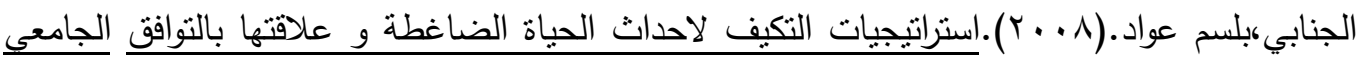

لادى طلبة الجامعة،كلية التربية ابن الهيثم،جامعة بغدادهرسالة ماجستير غير منشورة.

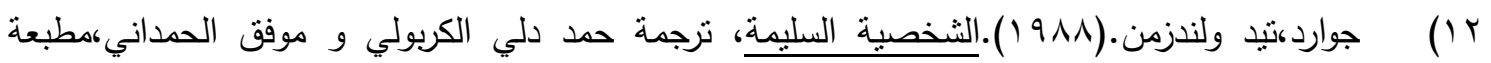

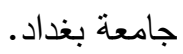

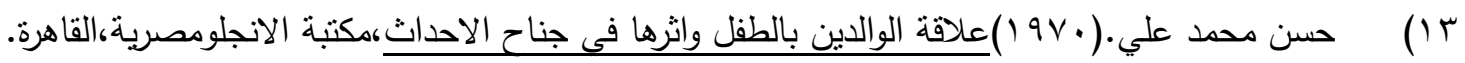

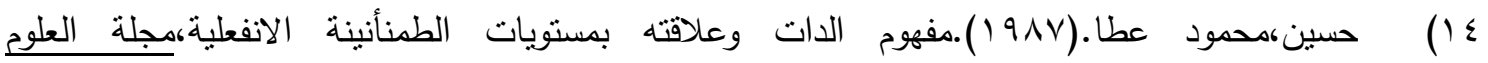

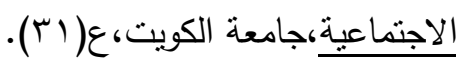
10) الحجاجي،يوسف.(917 (191).تصدع الثخصية في نضريات علم النفس،الهيئة المصرية الامة للكتاب.

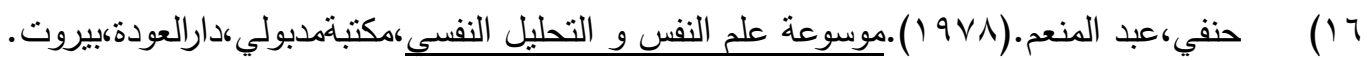




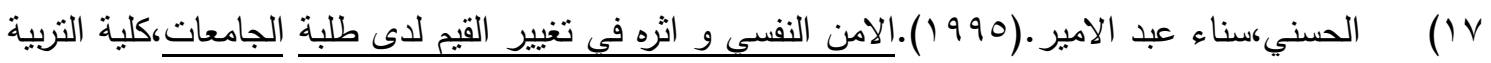
،الجامعة المستتصرية،رسالة ماجستير غير منشورة.

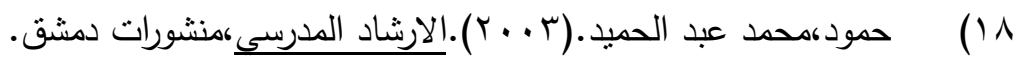

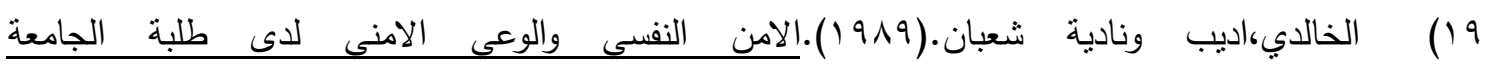
المستتصرية،المؤتمر السنوي في كلية التربية،الجامعة المستتصرية.

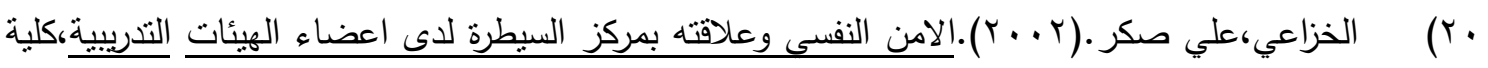
التربية،جامعة القادسية،رسالة ماجستير غير منشورة. (Y)

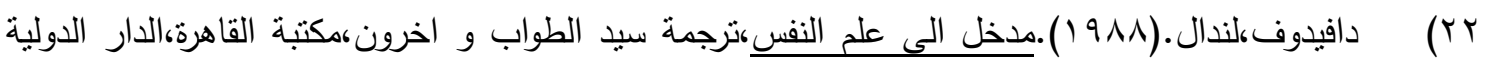
للتوزيع والنشر ،ط(ب). rr) الداليمي،احسان عليوي.(1991).التوافق الثخصى و الاجتماعى للمرشدين التزبويين في العراق ،كلية التربية ابن رشد،جامعة بغداد،رسالة ماجستير غبر منشورة.

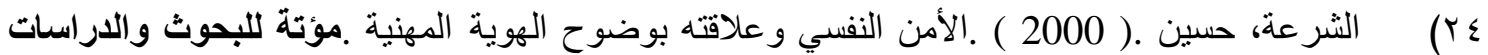
(3) ‘.205- 157 ،

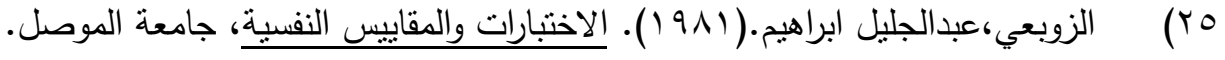

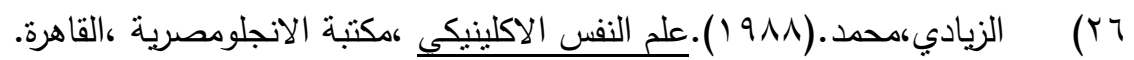
(YV

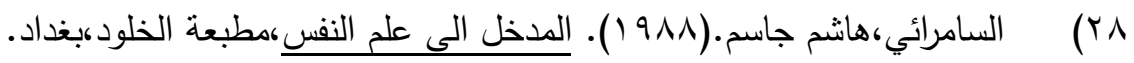

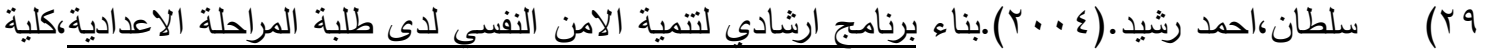
التربية،الجامعة المستتصرية،رسالة ماجستير غير منشورة.

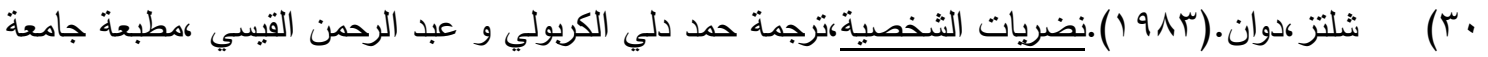

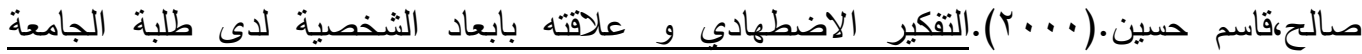

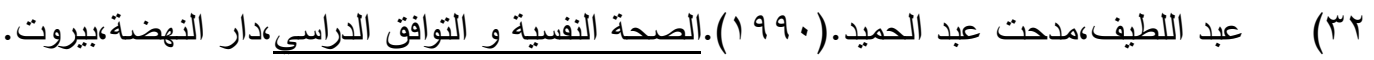

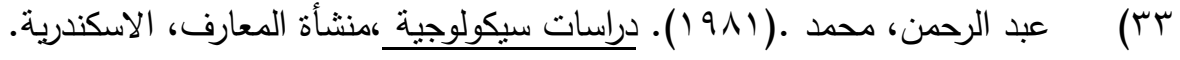

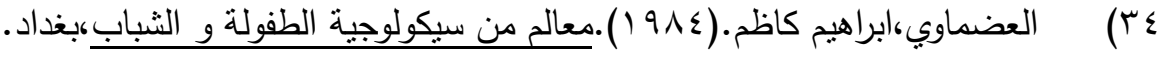

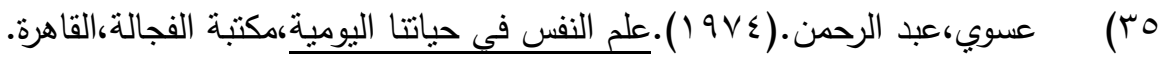
جr) عزام،احمد.(919(1).بعض المنغيرات المصاحبةالاغتراب الثباب عن المجتمع الجامعيهمجلة العلوم

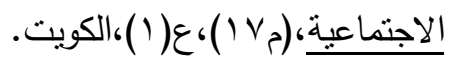
(YV

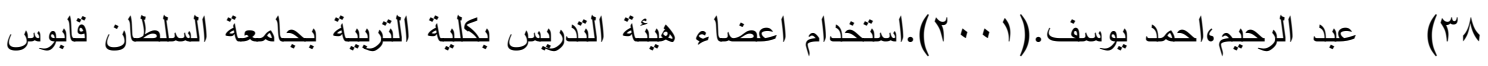

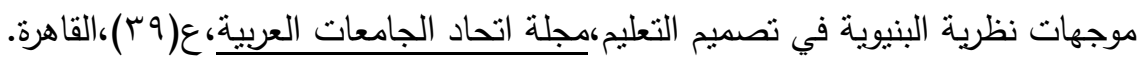

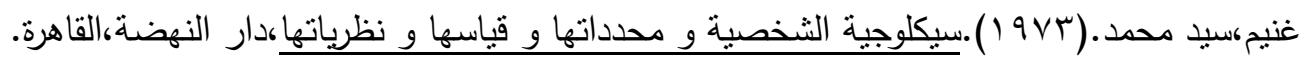


• •) غالي،محمد احمد.(71911).الانسان بين التخصص الاكاديمى و بين الميل العلمى بين طلاب جامعة الكويت ، مؤسسة الكويت للتقدم العلمي ، الكويت.

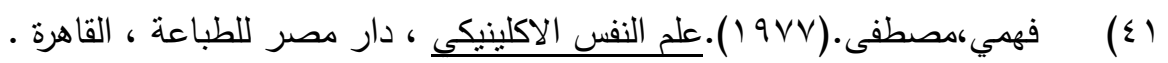

(

(

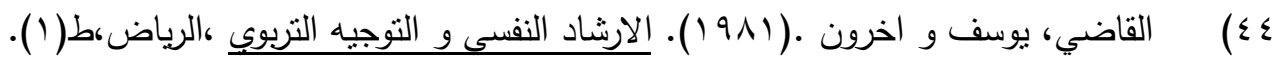

0؛) الكردي، مها.(•191). التوافق و التكيف الثخصي و الاجتماعي لدى اطفال الملاجئ ،المجلة الاجتماعية القومية ،ع| V )،القاهرة.

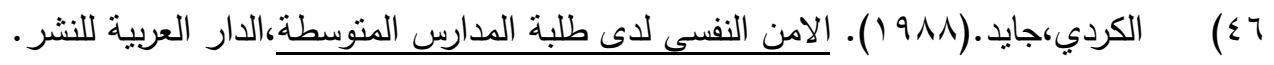

(乏V

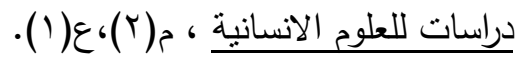

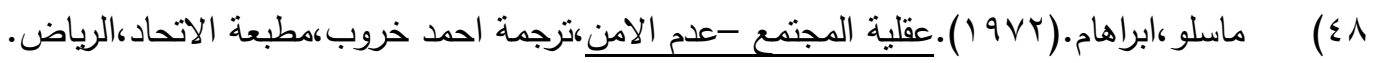

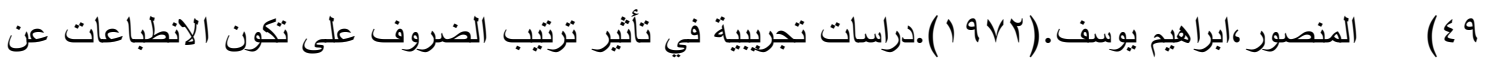

الثخص ، مجلة الجامعة المستصرية، ع(ب)، السنة الثالثة.

•) موسى،عبد الله الحي.(1911).بحوث في علم النفس التزبوب،مكتبة الخانجي،القاهرة.

(0)

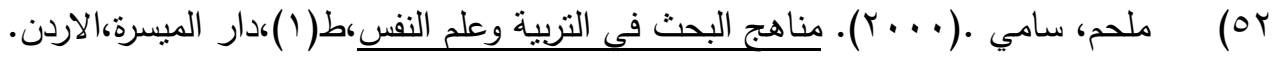

ro) مخيمر ،صلاح و رزق،ميخائيل.(1971 (1). سيكولوجية الثخصية،مكنبة الانجلو مصرية،القاهرة.

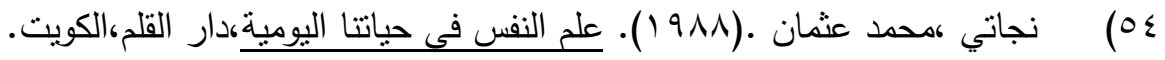

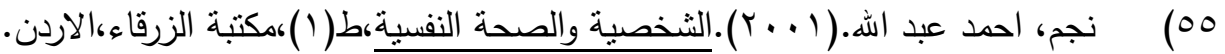

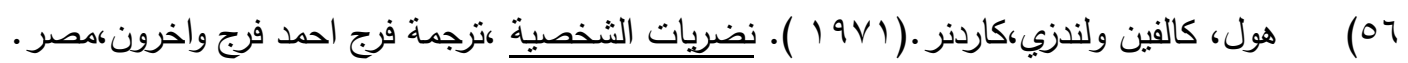

(ov

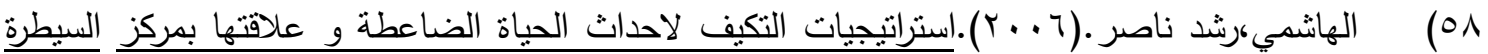

للدى مراهقى دور الدولة، كلية التربية ابن الهيثمجامعة بغداد،اطروحة دكتوراه غير منشورة.

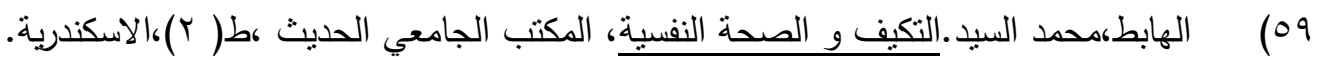

60) Alborto,p.(1986).applied behavior analysis, Merrille Bell \& howeni pub.

61) American psycholoatic Association. Diagnostic \& Statistical of Mentel Disorders $:$ D S M- $4.4^{\text {th }}$ ed. Washington,D.C: American psychiatric press:1994:1106-4116.

62) Anastasija.(1976). Psychological Testing, New York,macmillan pub.

63) Bennet ,G.M \& Jord , T.E.(1985). Security-Insecurty and the directions of Aggressive Responses to frstraion, Indian jornal of psychology.

64) Bishop,Report .(1970). The relationship of faculty members prece lived sence of security to the Instructional in novation in the community, college disserlation Abstract

65) Cole,C.\& Hall,L.(1970).Astudy of psychological adjustment,New Fetlance,London. 
66) Fatil, Raddy.A.N.(1985).Study of feclling of security - Insecurity,among propessinal and Non perfessinal students of cudarge city, Indian psychology R V.

67) Good, C.V.(1973).Dictionary of Education,MCGraw Hill co.New York.

68) Gorlow,Leon \& Walter,K.(1968). Reading in the psychology of Adjustment,MCGraw Hill co ,New York.

69) Harris , H . J . \& Anton, R . G .(1985). The Importanle of Assessing NeedS of Male and Femal College freshman.

70) Huffman, Karen et al .(2000).psychology in action , $\left(5^{\text {th }}\right.$ ed), New York, John wely \& sons Inc.

71) Lauzrus, Richards.(1969). Patterns of Adjustment and Human Effectiveness, MCGaw Hill com New York.

72) Lo,M. \& Hell . G .(1970). Person Environment occupation occupational, Jornal of accupational therapy,vol.(63).

73) Maslow, A .H .(1972). Motivation \& personality , (2th ed), Harper\& Row pub , New York.

74) Park ,C .H . C.(1982).Ethic Inddentificatio Sociocultural Adjstmentation International , 42 (10), 4602.

75) Perlman, D. Peplau, L.(1998). Lonliness. Encyclopedia of Mentelhealth: Acadmic press.

76) Rajecki , D. W. (1990).Attiudes Massa Chusetts, signor As. Pub. Rakes,

77) G . et al .(2001). An Ananlysis of psychological security \& constructivist Behaviors in teachers, Jornal of Adver tisting Reserch.

78) Stoner, K . L . (1981). Student satisfaction \&quality of life survey.

79) Suttons . S .(1997).The Relationship of Security Acceptance \& coping strategies , Journal Of Aplied.

الملاحق

\section{ملحق (1)}

$$
\text { بسمه تعالى }
$$

الجامعة المستتصرية/كلية التربية

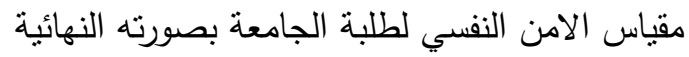

عزيز الطالب ...... - ع

$$
\text { يروم الباحث اجراء دراسته الموسومة(الامن النفسي لدى طلبة الجامعة). }
$$

ولتحقيق اهداف الدراسة يرجو الباحث تعاونكم بقراءة كل فقرة و الاجابة عليها على النحو الاتي:-

\begin{tabular}{|c|c|c|c|c|c|c|}
\hline ل & نادرا & احيانا & غالبا & دائما & الفقرة & ت. \\
\hline & & & & & يؤلمني قلة المساوة بين الطلاب. & \\
\hline
\end{tabular}

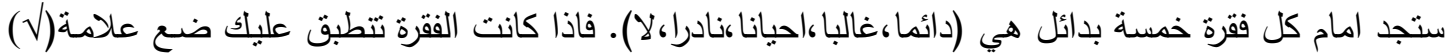

هذا مع العلم ان المعلومات التي ستشير اليها ستبقى سرية و ستستخدم لاغراض البحث العلمي فقط، وشكرا.

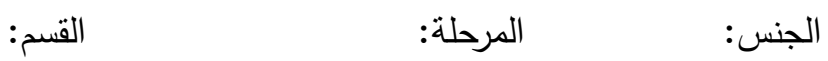


فقرات مقياس الامن النفسي بصورته النهائية.

\begin{tabular}{|c|c|c|c|c|c|c|}
\hline $\bar{\gamma}$ & نادرا & احيانا & غالبا & دائما & 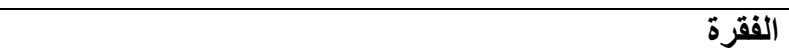 & ت \\
\hline & & & & & انامطمئن لنجاحي في حياتي الاراسية. & .1 \\
\hline & & & & & يؤلمني قلة المساواة بين الطبة. &.$r$ \\
\hline & & & & & اشعر بالّراحة عند وجودي في قاعة الدرس &.$r$ \\
\hline & & & & & اتألم بسبب عدم تلبية حرية اختيار الثعبة التي ادرس بها. & \& \\
\hline & & & & & اثعر بالطمائنينة عند ممارسة النشاطات المدرسية. & .0 \\
\hline & & & & & احب التعامل مع زملائي الطلبة. & .7 \\
\hline & & & & & امتلك حرية التعبير عن ارائي و افكاري دون خوف من الاساتذة. &. $\mathrm{V}$ \\
\hline & & & & & افرح عندما يطلب مني شرح الدرس. &.$\wedge$ \\
\hline & & & & & اتصبب عرقا عندما يستدعيني رئيس القسم. & .9 \\
\hline & & & & & اعتمد على نفسي في حل مشاكلي الدراسية. & . 1. \\
\hline & & & & & قلبي مليء بالحب لاساتذتي. ق & .11 \\
\hline & & & & & اتمكن من تحقيق اهدافي في الحياة. & .14 \\
\hline & & & & & يضايقتي وجود طلاب افْضل مني. & .14 \\
\hline & & & & & اتخوف من علدم امكانيتي في كسب حب و تقدير الاساتذة. & $.1 \leqslant$ \\
\hline & & & & & اشعر باني محبوب في القّسم. & .10 \\
\hline & & & & & اشعر بطول اليوم الدراسي. & .17 \\
\hline & & & & & اشعر بالوحلة و انا بين زملائي. &. $\mathrm{IV}$ \\
\hline & & & & & اشعر بالانزعاج عندما اتأخر عن الدوام. & .11 \\
\hline & & & & & يسرني الاشتراتك في الاعمال الجماعية. & .19 \\
\hline & & & & & اخاف أن يعرف الاستاتذة حقيقتي. &.$r \cdot$ \\
\hline & & & & & اشعر بأن اصدقائي الطلبة مخلصون لي. & .4 \\
\hline & & & & & اشعر بالخوف من رئيس القسم. & QY \\
\hline & & & & & اترك الدوام بدون اجازة كلما اتيح لي المجال. & rr \\
\hline & & & & & اتفاعل بسرعة مع زملائي الطلبة. & 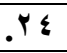 \\
\hline & & & & & احرص على الوصول الى الكلية قبل الدوام. &. YO $^{\circ}$ \\
\hline & & & & & يسعدني رضا الاساتذة عني. & .47 \\
\hline & & & & & اشعر بأن عيون الطلبة تلاحقني في كل مكان. &. $\mathrm{TV}$ \\
\hline & & & & & سلوك الاساتذة يزودني باستقرار نفسي. &. $\mathrm{r}$ \\
\hline & & & & & تكون معنوياتي منخفضة قبل الامتحان. & .19 \\
\hline & & & & & ارتاح عندما ينتهي اليوم الدراسي. &.$r \cdot$ \\
\hline & & & & & يقلقني عندما يبداء الاستاذ بتوجيه الاسئلة . & .1 \\
\hline & & & & & يفرحني معرفة الاساتذة اسمي. &.$\mu r$ \\
\hline & & & & & اشعر بأني لاستطيع السيطرة على مشاعري. &.$r r$ \\
\hline & & & & & افرح عندما اشارك الطلبة افراحهم. & r \\
\hline & & & & & اشعر بالراحة عند دخولى قاعة الدرس. & ro \\
\hline
\end{tabular}

\section{ملحق (r)}

مقياس التوافق الجامعي بصورته التهائية

الجامعة المستتصرية/كلية التربية

يروم الباحث اجراء دراسته الموسومة(التوافق الجامعي لدى طلبة الجامعة). ولتحقيق اهداف الدراسـة يرجو

الباحث تعاونكم بقراءة كل فقرة و الاجابة عليها على النحو الاتي:-

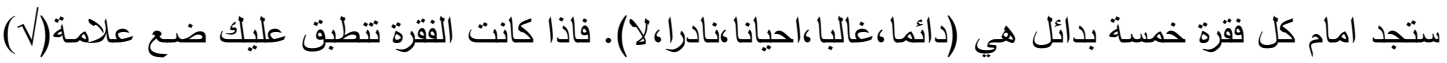

تحت البديل الذي ينطبق عليك وكما هو موضح.

\begin{tabular}{|c|c|c|c|c|c|c|}
\hline$\gamma$ & نادرا & احيانا & غالبا & دائما & الفقرة & ت. \\
\hline & & & & & اهتم بمشكلات الاخرين. & 1 \\
\hline
\end{tabular}

هذا مع العلم ان المعلومات التي سنتير اليها ستبقى سرية و ستستخدم لاغراض البحث العلمي فقط، وشكرا. 


$$
\begin{aligned}
& \text { القسم: } \\
& \text { المرحلة: }
\end{aligned}
$$

\begin{tabular}{|c|c|c|c|c|c|c|}
\hline ע & نادرا & احيانا & غالبا & دائما & 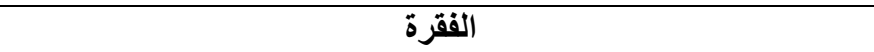 & ت. \\
\hline & & & & & اشعر بأهمية المواد التي ادرسها. & .1 \\
\hline & & & & & يكسبني التحاقي بالجامعة خبرات و مهارات كثيرة. &.$r$ \\
\hline & & & & & درجاتي في الكثير من المواد الاراسية تنخفض من وقت لاخر. &.$r$ \\
\hline & & & & & اشعر بهمة ونثاط عندما يبدأ اليوم الدراسي. & \& \\
\hline & & & & & أواجه صعوبة في مفردات المواد الاراسية. & .0 \\
\hline & & & & & اتمنى ان لاتفوتني اية محاضرة طيلة الوقت. & .7 \\
\hline & & & & & اشعربالرضا عن تخصصي الدراسي. &.$\vee$ \\
\hline & & & & & ارتاح لغياب التدريسين عن المحاضرات. &.$\wedge$ \\
\hline & & & & & يهمني التحصيل العلمي اكثر مما يهمني الحصول على الدرجات العالية. & .9 \\
\hline & & & & & طموحي ان اكون استاذا جامعيا. & .1 . \\
\hline & & & & & اشعر ان زملائي يحترمونني. & .11 \\
\hline & & & & & اشعر بالرغبة في التعاون مع اساتذتي في القسم. & $.1 Y$ \\
\hline & & & & & ابادر لتقديم المساعدة الى من يحتاج اليها. & .14 \\
\hline & & & & & اجد كل احترام و معاملة حسنة في هذه الكلية. & $.1 \leqslant$ \\
\hline & & & & & اتقبل انتقادات الاخرين برحابة صدر. & .10 \\
\hline & & & & & اشعر بتعاطف الاخرين وحبهم لي. & .17 \\
\hline & & & & & التزم بانظمة الكلية وقو انينها. & $.1 \mathrm{~V}$ \\
\hline & & & & & افتخر باتتمائي لهذه الكلية. & .11 \\
\hline & & & & & اشعر بالغيرة عندما يتفوق زملائي علي. & .19 \\
\hline & & & & & اعاني من الثرود الذهني اثناء المحاضرات. & r. \\
\hline & & & & & اغضب لاتفه الاسباب. & .4 \\
\hline & & & & & تراودني المخاوف بين الحين و الاخر. & $\overline{. r Y}$ \\
\hline & & & & & استغرق باحلام اليقضة في اثناء المحاضرات. &.$r T$ \\
\hline & & & & & يتغير مزاجي بين الحين و الاخر. & 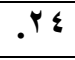 \\
\hline & & & & & استعيد الهدوء بعد زوال سبب الاثارة. &. YO $^{\circ}$ \\
\hline & & & & & اشعر بالسعادة عندما اسمع الموسيقى. & T4 \\
\hline & & & & & اشعر بالراحة في اثناء و جودي مع الاخرين. &.$r V$ \\
\hline & & & & & يلازمني سوء الحظ في اثثاء دراستي. &..$^{\top \wedge}$ \\
\hline & & & & & اود ترك الدراسة في الكلية. &..$^{9}$ \\
\hline & & & & & اهتم بمشكلات الاخرين. &.$r$ \\
\hline & & & & & اشـارك الناس افراحهم و احزانهه. & r l \\
\hline & & & & & اشعر بالخجل من الاخرين. &.$r r$ \\
\hline & & & & & افضل الانعزال عن الاخرين. &.$r r$ \\
\hline & & & & & اتعرف بيسر على زملائي في الكلية. & $. r \leqslant$ \\
\hline & & & & & اثق قدراتي على تحقيق النجاح. &.${ }^{\mu 0}$ \\
\hline & & & & & اعتقل انني سوف احقق احلامي في المستقبل. & .47 \\
\hline & & & & & اكون هادي الاعصاب في المواقف الحرجة. &.$r v$ \\
\hline & & & & & احب الناس الذين اعيش معهر. &.$r \wedge$ \\
\hline & & & & & اتمني السعادة لافراد اسرتي. & .49 \\
\hline & & & & & ارغب في مساعدة الناس جميعا. & . \\
\hline
\end{tabular}

فقرات مقياس التوافق الجامعي بصورته النهائية. 


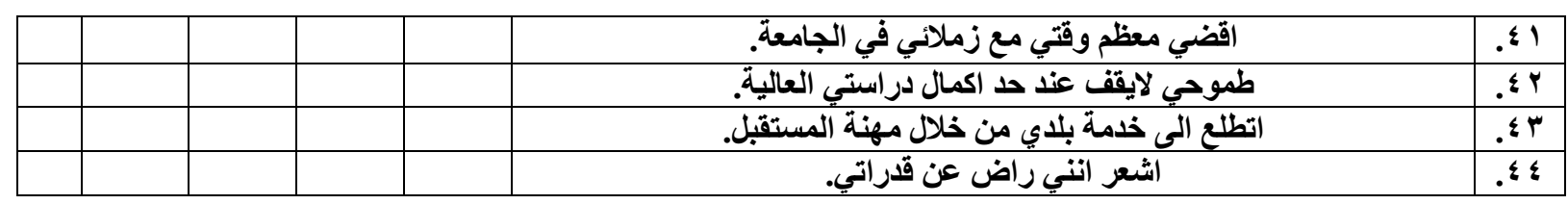

الملحق رقم (r)

$$
\begin{aligned}
& \text { اسماء الخبراء: } \\
& \text { ا ..د محمد سعود. } \\
& \text { ا.د كفاح العسكري } \\
& \text { ا.م.د عبد الكريم جعو . } \\
& \text { ا.م.د بشرى كاظم الثمري } \\
& \text { ا.م.د نجلاء وداعة }
\end{aligned}
$$

\title{
Psychological security and its relationship with to the University compatibility with the students of the College of Education at the University of Mustansiriya Prof. Dr. Abdul al-Hussein Majid Rezouki M.Dr. Atheer Aday Salman al- Quraishi M.Dr. Haider Lazim Khudair
}

\begin{abstract}
:
The psychological security to one of the most modern world drives where increased research that addressed the importance and influence in a lot of political and economic aspects, psychological, especially when university students who are the most important slides that have an important role in the construction of any society slice, man security is a human being capable of production and Dungeons against psychological tremors, personal understanding of university students is to assess the extent Daffiest and that is the most important security engines, as it is a key demand for compatibility, security is a human being who is capable of building successful relationships with others.

Targeting current research into the psychological security measure and its relationship University compatibility among university students and prepared by (Sultan, 2002) eventually adapted to fit with the university students and which consists of (35) items of each paragraph five alternatives, also was adopted university compatibility-drafted measure (al-Janabi, 2008), which consists of (44) items each with five alternatives, as has been verified validity and reliability have been applied to a sample of 100 students and a student at the College of Education, Al-Mustansiriya University, where results showed that male safer than females and to the lack of clear differences in university compatibility between the gender.
\end{abstract}

